\title{
Contribution of Tropical Cyclones to the North Pacific Climatological Rainfall as Observed from Satellites
}

\author{
Edward B. Rodgers 1, Robert F. Adler 1 \\ and Harold F. Pierce 2 \\ 1. Laboratory for Atmospheres, NASA/Goddard Space Flight Center, Greenbelt, MD. \\ 20771 \\ 2. Science Systems and Applications, Inc., Lanham, MD. 20706
}

\section{August 1999}

Submitted to Journal of Applied Meteorology

Corresponding author address: Dr. Edward B. Rodgers Mesoscale Amospheric Processes Branch (Code 912) Laboratory for Atmospheres, NASA/Goddard Space Flight Center, Greenbelt, MD. 20771. 


\begin{abstract}
Tropical cyclone monthly rainfall amounts are estimated from passive microwave satellite observations for an eleven year period. These satellite-derived rainfall amounts are used to assess the impact of tropical cyclone rainfall in altering the geographical, seasonal, and inter-annual distribution of the North Pacific Ocean total rainfall during JuneNovember when tropical cyclones are most important.
\end{abstract}

To estimate these tropical cyclone rainfall amounts, mean monthly rain rates are derived from passive microwave satellite observations within $444 \mathrm{~km}$ radius of the center of those North Pacific tropical cyclones that reached storm stage and greater. These rain rate observations are converted to monthly rainfall amounts and then compared to those for non-tropical cyclone systems.

The main results of this study indicate that: 1) tropical cyclones contribute $7 \%$ of the rainfall to the entire domain of the North Pacific during the tropical cyclone season and $12 \%, 3 \%$, and $4 \%$ when the study area is limited to, respectively, the western, central, and eastern third of the ocean; 2 ) the maxima in tropical cyclone rainfall are poleward $\left(5^{\circ}\right.$ to $10^{\circ}$ latitude depending on longitude) of the maxima in non-tropical cyclone rainfall; 3) tropical cyclones contribute a maximum of $30 \%$ northeast of the Philippine Islands and $40 \%$ off the lower Baja California coast; 4) in the western North Pacific, the tropical cyclone rainfall lags the total rainfall by approximately two months and shows seasonal latitudinal variation following the ITCZ; and 5) in general, tropical cyclone rainfall is enhanced during the El Niño years by warm SSTs in the eastern North Pacific and by the monsoon trough in the western and central North Pacific. 


\section{Introduction}

The main driving force of the time averaged planetary scale motions of the earth's atmosphere is provided by quasi-stationary heat sources generated by the combination of latent heat release (LHR) and radiative processes, in which LHR is the larger. Therefore, the knowledge of the spatial and temporal variation of rainfall is fundamental in understanding and modeling the anomalies of the general atmospheric circulation (Huffman et. al 1997: Berg and Avery, 1994; Wang, 1994; Waliser and Gauther, 1993; Janowiak and Arkin, 1991). An important source of latent heat over the tropical and subtropical oceans is the tropical cyclone. It has been demonstrated that the average rain rate within $111 \mathrm{~km}$ of the center of western North Atlantic hurricanes (Rodgers et al., 1994) and western North Pacific typhoons (Rodgers and Pierce, 1995) is approximately $7 \mathrm{~mm} \mathrm{~h}^{-1}$ as compared to an

average rain rate of $5 \mathrm{~mm} \mathrm{~h}^{-1}$ within $111 \mathrm{~km}$ of the center of western North Atlantic and Pacific depressions or large convective systems. Also, the generation of LHR by tropical cyclones can be greater than tropical convective systems due to their size and multi-scale interaction. However, their frequency of occurrence is much less than rain producing systems found, for example, in the inter-tropical convergence zone (ITCZ).

Therefore, questions remain concerning the impact of tropical cyclones on the general circulation. For example, quantitative information about the role of these systems in distributing rainfall is critical to understanding the impact that tropical cyclones have in altering the synoptic and seasonal scale general circulation patterns of the North Pacific. To be more specific, questions concerning the following subjects may be answered from this tropical cyclone rainfall analysis: 1) how much additional rainfall do tropical cyclones contribute during the tropical cyclone season to the tropical and subtropical regions of the North Pacific; 2) where and when does the greatest contribution of tropical cyclone rainfall occur; 3) can large-scale atmospheric changes (e.g., El Niño) alter the sea surface 
temperatures (SSTs) and the atmospheric circulations and, thereby, affect the frequency, intensity, and/or location of tropical cyclones; and 4) do tropical cyclones alter the geographical patterns of rainfall (diabatic heating) and, thereby, influence the general circulation patterns (e.g., Hadley Cell)?

In this study, monthly North Pacific tropical cyclone rainfall and the rainfall generated by all other North Pacific systems is determined using data from the Special Sensor Microwave/Imager (SSM/I) instruments on board the Defense Meteorological Satellite Program (DMSP) satellites. The SSM/I observations are collected over the North Pacific $\left(0^{\circ}-45^{\circ} \mathrm{N}\right.$ by $\left.100^{\circ} \mathrm{E}-80^{\circ} \mathrm{W}\right)$ during the months of June - November when tropical cyclones are most abundant for the years of 1987-1989 and 1991-1998 (there was little available 1990 SSM/I data). These monthly rainfall observations for the North Pacific tropical cyclones are then used to examine geographical, seasonal, and inter-annual variations in North Pacific tropical cyclone rainfall.

\section{Data Analysis}

a. Special Sensor Microwave/Imager (SSM/I)

The DMSP satellites circle the globe 14.1 times per day along a near sunsynchronous orbit at an altitude of $833 \mathrm{~km}$ and a $98.8^{\circ}$ inclination. The SSM/I sensors on board DMSP F-8, F-10, F-11, F-13, and F-14 satellites measure reflected and emitted dual polarized microwave radiation at frequencies of $19.4,37.0$, and $85.5 \mathrm{GHz}$ and vertically polarized microwave radiation at $22.2 \mathrm{GHz}$. The SSM/ls scan conically at a $45^{\circ}$ angle from nadir and have an observational swath width of approximately $1400 \mathrm{~km}$ at the earth's surface. The F-8 DMSP SSM/I was fully operational from the first week of July 1987 to February 1990. The F-10 DMSP SSM/I was partially operational from December 1990 to 
January 1992 and then became fully operational. The F-11 DMSP SSM/I had been fully operational since January 1992. The F-13 and F-14 were, respectively, launched May 1995 and May 1996 and have been fully operational ever since. The ascending (descending) F-8, F-10, F-11, F-13, and F-14 DMSP orbits, respectively, cross the equator near the eastern North Pacific at approximately 00:20 (1 1:50), 04:05 (16:30), 01:34 (13:08), 23:35 (12:08), and 01:47 (14:29) UTC. Further information concerning the SSM/I sensor measurements and orbital mechanics is documented by Hollinger et al. (1991).

\section{b. SSM/I brightness temperature/rain rate algorithm}

Rain rates are obtained from the SSM/I-derived brightness temperatures by utilizing an algorithm developed by Adler et al. (1994). The algorithm is called the Version 2 Goddard Scattering Algorithm (GSCAT-2). The algorithm uses a combination of the 37.0, 22.2, and $19.4 \mathrm{GHz}$ channels to define potential raining regions and the $85.5 \mathrm{GHz}$ channel to derive rain rates greater than $1 \mathrm{~mm} \mathrm{~h}^{-1}$ within the raining areas. Both the rain criterion and the rain rate and brightness temperature relationship are based on a cloud model calculation (Adler et al, 1991). The algorithm is chosen for its computational simplicity and because it utilizes the SSM/I channel (i.e., $85.5 \mathrm{GHz}$ ) with the best spatial resolution (i.e., 15 by $15 \mathrm{~km}$ ) to measure rain rates. Areal mean rain rates derived from SSM/I for the inner core (i.e., within $111 \mathrm{~km}$ of the center) of the 1987-89 western North Atlantic tropical cyclones using the GSCAT-2 algorithm are found (see Table 2 in Rodgers et al. 1994) to compare favorably with most of the early estimates that are obtained from rain gages, water vapor budget studies, and earlier satellite-based microwave observations. 


\section{c. Sampling technique}

To assemble the tropical cyclone rainfall data, SSM/I-derived tropical cyclone rain rates are used to estimate mean monthly tropical cyclone rainfall amounts. Only the rain rates that are observed within $444 \mathrm{~km}$ of the center of the circulation of North Pacific tropical cyclones by SSM/I are used. This tropical cyclone rain rate sampling area is chosen to encompass the majority of the rainfall that is associated with the mean domain of the tropical cyclone lower-tropospheric circulation, containing the eye wall and rain bands. The approximate number of SSM/I pixels sampled in the region are 2000. The centers of the tropical cyclones for the time of the SSM/I passes are extrapolated from the best track data. Information concerning the intensity and position of the North Pacific tropical cyclones can be found at the National Climate Data Center.

The analysis area for this study covers both land and ocean regions of the North Pacific that is divided into three regions. These regions are the western (i.e., $5^{\circ}-35^{\circ} \mathrm{N}$ and $100^{\circ}-160^{\circ} \mathrm{E}$ ), the central (i.e., $5^{\circ}-35^{\circ} \mathrm{N}$ and $160^{\circ} \mathrm{E}-140^{\circ} \mathrm{W}$ ), and the eastern (i.e., $5^{\circ}-35^{\circ} \mathrm{N}$ and $140^{\circ}-80^{\circ} \mathrm{W}$ ) North Pacific. The three North Pacific domains are arbitrarily chosen in order to partition the ocean basin into equal geographical areas and to eliminate regions of the North Pacific where tropical cyclones are rarely observed (i.e., latitudes less than $5^{\circ} \mathrm{N}$ )

or adversely influenced by strong vertical wind shear that is greater than $10 \mathrm{~ms}^{-1}$ and/or SSTs less than $26^{\circ} \mathrm{C}$ (i.e., latitudes greater than $35^{\circ} \mathrm{N}$ ).

In the majority of the cases, the SSM/I observations that are within the circular area of $444 \mathrm{~km}$ are able to capture most of the tropical cyclone rainfall when the systems pass within view of SSM/I. Within the $444 \mathrm{~km}$ domain, the SSM/I sensors are able to monitor the rain rates at least once for 706 western, 194 central, and 390 eastern North Pacific tropical cyclones that reached storm stage (Vmax $>17 \mathrm{~m} \mathrm{~s}^{-1}$ ) and greater. From these 
observations, the SSM/I tropical cyclone rain rate samples include 254 depressions, 24.3 storms, and 209 typhoons in the western North Pacific, 91 depressions, 72 storms, and 31 typhoons/hurricanes in the central North Pacific, and 135 depressions, 153 storms, and 102 hurricanes in the eastern North Pacific. The sample does not include tropical depressions that never reached storm stage. Also, for tropical cyclones that occur over land, the SSM/I-derived rain rates are only sampled for dissipating tropical cyclones that are followed by the best track reports. Therefore, for these reasons the study will slightly underestimate the total tropical cyclone rainfall.

To estimate the monthly tropical cyclone rainfall, the SSM/I-derived rain rates that are sampled within $444 \mathrm{~km}$ of the center of each tropical cyclone are accumulated and averaged for a $2.5^{\circ}$ latitudinal/longitudinal grid and then multiplied by the number of hours for that given month using equation 1 :

$$
R A_{\text {cyclome }}=\frac{\sum R_{\text {cyclone }}}{\sum \text { Pixels }_{s S M / l}} X \text { Hours }_{m o n t h}
$$

where:

$\begin{aligned} R A_{\text {cyclone }}=\quad & \text { Rainfall amount per month }\left(\mathrm{mm} \mathrm{month}^{-1}\right) \text { contributed by } \\ & \text { tropical cyclones within a } 2.5^{\circ} \text { latitudinal/longitudinal grid } .\end{aligned}$

$R R_{\text {cyclone }}=\quad \mathrm{SSM} / \mathrm{I}$ observed rain rate $\left(\mathrm{mm} \mathrm{h}^{+}\right)$contributed by tropical cyclones during a given month within a $2.5^{\circ}$ latitudinal/longitudinal grid.

Pixels $S S M / I=$ Total number of SSM/I pixels. 


\section{Hoursmonth $=$ Number of hours in a given month.}

These values will be referred to as "tropical cyclone rainfall" in the remaining portion of this text.

The total rainfall from all systems is then calculated by considering all SSM/l observations and will be referred to as "total rainfall" in the remaining portion of this text. Finally, the non-tropical cyclone rainfall is calculated from the difference between the monthly mean total rainfall and that estimated from tropical cyclones and will be referred to as "non-tropical cyclone rainfall" in the remaining portion of this text.

\section{d. Sampling characteristics}

Using SSM/I frequencies to estimate the mean monthly rainfall during the eleven year period can introduce two significant errors within each grid box. The first type of error is related to the conversion of the SSM/I measurements into rainfall estimates ("retrieval errors") and the second type of error is related to the lack of continuous SSM/Is coverage ("sampling errors"). Bell et al. (1996) argued that the SSM/I sampling errors usually dominate the random retrieval errors when the retrieval errors are uncorrelated from one retrieval to another. There can still be remaining systematic retrieval errors, but since this study deals primarily with the relative contribution of tropical cyclone rainfall, the systematic errors (bias) are not important in reaching the conclusions in this study.

Assuming that there is no data loss from the SSM/I, the number of SSM/I observations during the month over a $2.5^{\circ}$ latitude/longitude area (e.g., the sampling area 
used for this study) for the given DMSP orbital parameters are approximately 32 (36) at 5 $\left(55^{\circ}\right) \mathrm{N}$ latitude (Bell et al., 1996). Also, if it were assumed that the rainfall statistics are similar to that found during the Global Atlantic Tropical Experiment (GATE) (Laughlin, 1981), the percentage error caused by SSM/I rainfall observational frequency within the given area of $2.5^{\circ}$ latitude/longitude is approximately $22 \%$ at both $5^{\circ}$ and $35^{\circ}$ latitude (Bell et al., 1996). The percentage error is considered to be the root-mean-square error divided by the mean error. The percentage error would be greater in regions where the frequency of rain events is less than that observed in the GATE region (e.g., eastern and central subtropical North Pacific) and less in regions where the frequency of rain events are greater than that found in the GATE region (e.g., in the ITCZ and tropical cyclones where rain events showed a high auto-correlation). The percentage error would also increase for grid boxes of lower mean rainfall. Further, since a single SSM/I only samples an area of the North Pacific twice a day, the sensor can cause another sampling problem by introducing a diurnal bias to the rainfall data depending on the strength of the diurnal variation.

Finally, there can be an additional sampling problem caused by the non-uniformity of the SSM/I observations by having more than one SSM/I to estimate rainfall (e.g., dual observations from F-10 and F-1I during 1992). By utilizing the GATE data and assuming that both SSM/Is view the grid boxes equally, it was demonstrated by Bell et al. (1996) that the dual SSM/I observations will increase the sampling error if the mean rainfall in a grid box is small and the diurnal variation of rainfall is large compared to the variability of the $\mathrm{SSM} / \mathrm{I}$ rainfall estimates. The relative sampling error is the sampling error divided by the mean rainfall percentage.

In this study, no attempt is made to alleviate these sampling problems by augmenting the SSM/I rainfall data with additional rainfall data sets developed from geosynchronous satellite observations (Adler et al., 1994) and rain gage network 
information [Huffman et. al., 1995 and 1997). However, to make the frequency of the SSM/I observations more homogeneous from year to year and from month to month, the following adjustments to the SSM/I-derived mean rainfall data sets are made. First, the accumulated monthly rainfall amounts for the inter-annual rainfall analyses are generated from a single SSM/I satellite from 1992-1998 when multiple SSM/I were flown. For the other rainfall analyses, all available SSM/I data are used. Second, since DMSP F-8 SSM/I was not operational until after June 1987 and during the tropical cyclone season of 1990 , the mean inter-annual rainfall data set was limited to the months of July-November. Further, the mean seasonal rainfall analyses for the months of June - November only contain the years of 1988-1989 and 1991-1998 (e.g. total of 10 years).

\section{e. Diagnostic products}

To assess the synoptic scale differences between the North Pacific tropospheric circulation and SSTs of the strong El Niño and La Niña years of 1987 and 1988. respectively, mean monthly lower-tropospheric and SST observations are examined only for the month of September, the height of the tropical cyclone season. The mean monthly tropospheric diagnostics are constructed from the re-analysis quantities generated by NASA's Goddard Space Flight Center Data Assimilation Office (DAO) atmospheric general circulation model (Schubert et al., 1993), which is most recently referred to as the Goddard Earth Observing System-1 (GEOS-1) System. The mean monthly selected quantities are produced during the post-processing steps of the assimilation cycle of the atmospheric general circulation model. The standard horizontal resolution of the model is $2.0^{\circ}$ latitude by $2.5^{\circ}$ longitude with a vertical resolution of 20 standard sigma levels. Global monthly mean SSTs for a given year are provided by the National Meteorological Center and averaged for a $2.5^{\circ}$ latitude/longitude horizontal grid (Reynolds and Smith, 1994). 


\section{Results}

a. Geographical distribution of tropical cyclone and non-tropical cyclone rainfall.

The upper, middle, and lower panels of Fig. 1 show, respectively, the geographical distribution of the mean monthly non-tropical cyclone rainfall, the tropical cyclone rainfall, and the percentage of rainfall contributed by tropical cyclones (i.e., the ratio of the tropical cyclone rainfall to the total rainfall) over the North Pacific area for this 65 month period. The upper panel of Fig. I indicates that the regions with the greatest non-tropical cyclone rainfall (i.e., greater than $300 \mathrm{~mm} \mathrm{month}^{-1}$ ) are associated with the ascending branch of the Hadley circulation that helps to maintain the ITCZ and the western North Pacific monsoon trough. Regions of moderate non-tropical cyclone rainfall (i.e., greater than $200 \mathrm{~mm}$ month ${ }^{-1}$, but less than $300 \mathrm{~mm} \mathrm{month}^{-1}$ ) appear to be associated with a region of weak 10 moderate ascending motion that extends from the western North Pacific monsoon trough northeastward into the westerlies. Finally, regions of light non-tropical cyclone rainfall

(i.e., less than $200 \mathrm{~mm} \mathrm{month}^{-1}$ ) appear to be associated with the descending branch of the Hadley circulation over vast subtropical regions (i.e., $15^{\circ}-35^{\circ} \mathrm{N}$ ) of the central and eastern North Pacific, eastern China, and western North America. The non-tropical cyclone mean monthly rainfall during the 65 month period are found to be, respectively, 246, 154, 188 , and $187 \mathrm{~mm} \mathrm{month}^{-1}$ for the western, central, and eastern North Pacific and for the entire North Pacific domain.

The middle panel of Fig. I suggests that the maximum tropical cyclone mean monthly rainfall is concentrated in the tropical and subtropical regions of the western and eastern North Pacific and the South China Sea. Little, if any rainfall is contributed by tropical cyclones near the equator, along the international date line, and north of $35^{\circ} \mathrm{N}$. The mean monthly rainfall contributed by tropical cyclones during the period are found to 
be, respectively, 34, 4, 8 , and $14 \mathrm{~mm} \mathrm{month}^{-1}$ for the western, central, and eastern North Pacific, and for the entire North Pacific domain.

The middle and lower panels of Fig. 1 indicate that the tropical cyclone rainfall is located slightly poleward of where the non-cyclone rainfall is concentrated. This is especially obvious in the percentage field (bottom panel). Within the region northeast of the Philippine Islands where the rainfall contributed by tropical cyclones is approximately $30 \%$ is an area where western edge of the North Pacific Tropical Upper Tropospheric Trough (TUTT) can be found and where tropical cyclones usually intensify rapidly (Holiday and Thompson, 1979). Within the central North Pacific, the greatest percentage of tropical cyclone rainfall is above $10 \%$ and is located in a dry region between $10^{\circ}-20^{\circ} \mathrm{N}$ latitude and $180^{\circ}-160^{\circ} \mathrm{W}$ longitude. In the eastern North Pacific, the greatest percentage of tropical cyclone rainfall is above $40 \%$ and is located in a region west of the Baja California coast $\left(25^{\circ} \mathrm{N}\right.$ and between $\left.110^{\circ}-140^{\circ} \mathrm{W}\right)$, north of the ITCZ. This feature reflects the intensification of tropical cyclones on the northern edge of the ITCZ and their movement toward the northwest, away from the ITCZ. The mean percentage of rainfall contribute by tropical cyclones during the period for the western, central, and eastern North Pacific is respectively, $12 \%, 3 \%$, and $4 \%$. For the entire domain, the value is $7 \%$.

Fig. 1 also suggests that tropical cyclones contribute significantly to the rainfall over land areas in Southeast Asia, providing a significant portion of rainfall important for food production in many areas. A $30 \%$ contribution due to tropical cyclones is evident in the northern islands of the Philippines, with lower, but significant, values in the rest of those islands. Central Vietnam also has significant tropical cyclone rainfall (over $20 \%$ ). with China, Taiwan and southern Japan having smaller percentages. However, it should be reemphasized that tropical cyclone rainfall amounts over the land and coastal regions may be underestimated in this study for the reasons given in section 2 . Also, shallow 
orographic rainfall (e.g., in Taiwan, Philippine Islands, and Japan) that is confined primarily below the freezing level may be missed or underestimated by the microwave technique, which is dependent on scattering due to ice to produce the necessary liquid.

Zonally-averaged profiles of rainfall for both tropical cyclones and non-tropical cyclonic systems are shown in Fig. 2 for the three ocean regions. In the western North Pacific, the maximum tropical cyclone rainfall is found at $16^{\circ} \mathrm{N}$, about $10^{\circ}$ north of the non-tropical cyclone rainfall maximum. Similar distributions are also evident in the central and eastern regions, but with a smaller $\left(5^{\circ}\right)$ displacement. Figs. 2a,b also indicate that at the latitude of peak tropical cyclone rainfall in the western North Pacific $\left(16^{\circ} \mathrm{N}\right)$, tropical cyclones contribute $25 \%$ to the total rainfall. In the central and eastern North Pacific these percentages are $8 \%$ and $12 \%$, respectively, with maxima located at $13-14^{\circ} \mathrm{N}$.

This analysis suggests that the eastern and central North Pacific maximum tropical cyclone rainfall values are lower than in the western North Pacific and the maximum is located further equatorward than that observed in the western North Pacific. This phenomena may be due to the fact that western North Pacific tropical cyclones are more numerous and intense and have a greater tendency to recurve into higher latitudes than those found in the central and eastern North Pacific.

b Seasonal variation of tropical cyclone rainfall

The seasonal variation of North Pacific tropical cyclone rainfall for the months of June-November is seen in Fig. 3. The figure shows that the maximum just east of the Philippine Islands is present in all the months with some latitudinal movement. The eastern North Pacific maximum is most prevalent in June-September. Southern Japan shows a significant variation during the season with a maximum in August and September. In the 
central North Pacific the eastern and western rainfall features seem to extend and meet in the months of August and September.

Figure 4 shows a histogram that delineates the seasonal variation of the non-tropical cyclone (black bars) and tropical cyclone (dashed bars) mean monthly rainfall amounts. The mean monthly rainfall and the percentage of rainfall contributed by tropical cyclones (percentage above the bar graph in the figure) suggest that tropical cyclones produce the most rainfall during the late summer and early fall months of September-October in the western North Pacific, lagging the maximum total rainfall in August. In the central and eastern North Pacific the lag is less obvious. Thus, tropical cyclone rainfall production appear to lag the months of maximum insulation more in the western North Pacific than in the central and eastern North Pacific. This lag is perhaps more related to the maximum warming of the SSTs and the maturity of the monsoon trough during early fall that have been proposed to be necessary conditions for the initiation of tropical cyclogenesis and tropical cyclone intensification.

Figure 5a, which shows the zonally averaged mean bi-monthly tropical cyclone rainfall in the western North Pacific during the six month period, shows an increase in maximum tropical cyclone rainfall above $15^{\circ} \mathrm{N}$ from June-July to August-September and then an equatorial shift of maximum rainfall to $11^{\circ} \mathrm{N}$ for October-November. In the central North Pacific (Fig. 5b) there is small equatorial shift and a sharp drop in magnitude to October-November. On the other hand, the eastern North Pacific (Fig. 5c) distribution indicates little latitudinal shift, but a sharp drop in magnitude to October-November. This lack of zonal shift in the eastern North Pacific may be due to the more zonal motion of these tropical cyclones and the strong meridional decrease in SSTs within the eastern North Pacific tropical latitudes. 
The geographic distribution of tropical cyclone rainfall contributed by depression. storm, and hurricane/typhoons is seen in Fig. 6. The figure shows that the greatest rain amounts observed during this eleven-year period in the western regions of the North Pacific are contributed by tropical cyclones of typhoon stage. This result is not surprising. However, the figure also shows that the greatest rain amounts observed during this period in the central and eastern regions of the North Pacific are not contributed by tropical cyclones of hurricane stage, but are, respectively, contributed by tropical cyclones of depression and storm stage. This result may be due to the fact that tropical cyclones of depression or storm stage were more frequent in these regions during this period than hurricanes. These statistics for the three sub-domains are shown in Fig. 7a. From this figure, typhoons in the western North Pacific are the dominant contributor, but that does not hold for the other areas.

Figure 7 shows that there are several obvious reasons why western North Pacific tropical cyclones produce more precipitation than their counterparts in the other regions. First, there are more tropical cyclones and, therefore, a greater number of tropical cyclone observations (number above the bar graph in Fig. 7a) in the western North Pacific than those found in the central and eastern North Pacific. Second, as demonstrated by Fig. 7b, the averaged rain rates within four $111 \mathrm{~km}$ wide annular rings surrounding the center of the western North Pacific tropical cyclones of typhoon intensity are greater than those of similar intensities in the central and eastern North Pacific.

The zonally averaged tropical cyclone rainfall as a function of intensity (Fig. 8) suggests that as the tropical cyclones become progressively more intense, there is a poleward shift (approximately $2.5^{\circ} \mathrm{N}$ in the western North Pacific; less in the other 
regions) in the location of the peak rainfall. This poleward shift appears to indicate how important the more intense tropical cyclones are in generating rainfall at higher latitudes. The reduction of the poleward shift in the central and eastern North Pacific is again probably related to the more zonal motion of the central and eastern North Pacific tropical cyclones and the narrow swath of warm SSTs.

\section{d. Inter-annual variation of tropical cyclone rainfall}

\section{1) RAINFALL OBSERVATIONS}

Based on the various ENSO indices, it has been suggested by some authors (Chan, 1985, Li, 1988, Wu and Lau, 1992) that El Niño years feature a reduction in the annual number of tropical cyclones in the western North Pacific region, while La Niña years favor an increase in the number of western North Pacific tropical cyclones. Ramage and Hori (1981) and Lander (1993), on the other hand, found no relationship between ENSO indices and the number of tropical cyclones in the western North Pacific. Lander (1993) also found no significant relationship between the strength of western North Pacific tropical cyclones and the ENSO indices. However, he did find a significant relationship between the SST variations and the number of tropical cyclones and their genesis location. $\mathrm{He}$ suggested that there is an easterly shift of the genesis region towards the central North Pacific during the El Niño years in response to the increasing SSTs of the central and eastern North Pacific and the eastward extension of the monsoon trough.

On the other hand, the total North Pacific rainfall estimates during the warm (1987) and the cool (1988) ENSO years from satellite-observed cloud top temperatures (Janowiak and Arkin, 1991), the Global Precipitation Climatology Project (GCPC) combined precipitation data sets (Huffman, et. a., 1997), and the NASA Goddard Institute for Space 
Studies GCM (Druyan and Hastenrath, 1993) indicate that there are large differences in the North Pacific total tropical rainfall. It is concluded from these studies that there are greater amounts of total North Pacific rainfall along the tropical latitudes, but less rainfall activity north of $10^{\circ} \mathrm{N}$ latitude during the El Niño year of 1987 as compared to the La Niña year of 1988. Further, there is a large eastward shift of the total North Pacific tropical rainfall during the El Niño year that corresponds closely to the eastward shift of the warm SST anomalies.

The tropical cyclone rainfall anomalies for each individual year are seen in Fig. 9. The rainfall anomalies are constructed by subtracting the July-November climatological tropical cyclone rainfall from the tropical cyclone rainfall amounts for each of the eleven years. The figure shows large inter-annual variations in the North Pacific rainfall contributed by tropical cyclones. Figure 10 shows the composite histograms for tropical cyclone and non-tropical cyclone rainfall for each year and for each basin. Also seen in the figure is the percentage of rainfall contributed by tropical cyclones. The time history of the Niño 3.4 SST anomalies in Fig. 11 shows that during July-November months of this 1987-1998 period there were three El Niño/La Niña events that clearly showed a positive SST anomaly followed by a distinct negative SST anomaly in the 3.4 Niño region $\left(5^{\circ} \mathrm{N}\right.$ $5^{\circ} \mathrm{S}$ and $120^{\circ}-170^{\circ} \mathrm{W}$ ) (Barnston and Ropelewski 1992). These two-year couplets (1987/1988, 1994/1995 and 1997/1998) are indicated in Fig. 10 with an E representing El Niño and L representing La Niña.

The three two-year pairs clearly show an ENSO signal in the patterns (Fig. 9) and the statistics (Fig. 10) in the tropical cyclone rainfall. The three EL Niño years (1987. 1996, 1997) show a very distinct increase in the western North Pacific and a smaller increase in the eastern north Pacific of tropical cyclone rainfall (Fig. 9). This relation is also obvious for these years in Fig. 10, where in the western North Pacific, the percentage 
of tropical cyclonic rain is $18 \%, 14 \%$, and $12 \%$ during the three El Niño years and drops to $8 \%, 8 \%$ and $6 \%$ during the La Nina years.

However, the pattern of activity (Fig. 9) and the statistics (Fig. 10) of the tropical cyclone rainfall during 1991 and 1992 would seem to indicate that these two years might have a similar relation to the ENSO SST index. This is not the case. The increasing SSTs anomalies that peaked during 1991 were not followed by negative SST anomalies in 1992 , but were followed by a longer period of generally above average SSTs in the Niño 3.4 region, although not as warm as 1991. During this period, the precipitation patterns, both non-tropical cyclone and tropical cyclone rainfall do not correlate with the SST anomalies. The underlying reasons for these inter-annual differences are not clear.

These relations between tropical cyclone rainfall and SST anomalies in the 3.4 Niño region for July-November months of each of the eleven years are examined for the western, central, and eastern North Pacific. A linear regression line (heavy line) and correlation coefficients are constructed and shown in Fig. 12. It should be mentioned that the horizontal scale in each panel of the figure is different. The graphs clearly show a positive correlation between these parameters in the western (.52), central (.16), and eastern (.57) North Pacific. On the other hand, the correlation coefficients between the ENSO SST index and non-tropical cyclone mean monthly rainfall for the eleven year period (figure not shown) in the western, central, and eastern North Pacific are, respectively ($.51),(.36)$, and (.37). The thin lines in Fig. 12 connect the El Niño/La Nina pairs of years mentioned earlier. In the eastern and western North Pacific regions these couplet years show tropical cyclone rainfall/SST variations with similar slopes, but with an apparent rainfall offset among the pairs. In the central North Pacific there is a much nosier signal. The reason for these offsets is unclear. 
The difference between the El Niño/La Niña pattern for the non-tropical cyclone and tropical cyclone rainfall across the North Pacific is shown in Fig. 13. The figure results from taking the difference in rainfall patterns between the El Niño years and the La Ninat years of the three couplet years. The top panel of Fig. 13 reveals that during the El Niño years there is a substantial increase in non-tropical cyclone rainfall within the ITCZ across the castern and central North Pacific and extending westward to $150^{\circ} \mathrm{E}$. and a smaller increase north of the ITCZ in the western North Pacific. On the other hand, there is less non-tropical cyclone rainfall during the El Niño years west of the Central America and southern Mexico coast, the South China Sea, and east of Japan.

The bottom panel of Fig. 13 clearly shows that the tropical cyclone rainfall is greater in western and eastern North Pacific during the El Niño years as compared to the La Niña years. It is also evident that during the El Niño years as compared to the La Niña years the maximum in tropical cyclone rainfall extends eastward towards the date line in the central North Pacific and is shifted poleward over the Philippine Islands of the western North Pacific. This eastward extension in tropical cyclone rainfall distribution has been suggested by Lander (1993) to be caused by the combination of warmer SSTs and the eastward extension of the monsoon trough. This may be the reason why Guam experiences more intense tropical cyclone during the El Niño years, since tropical cyclones develop and intensify more eastward of the island than during the average and the La Niña years.

The zonally averaged non-tropical cyclone and tropical cyclone mean monthly rainfall is shown in Fig. 14 for the three North Pacific Ocean basins. The western North Pacific zonally averaged mean non-tropical cyclone rainfall (Fig. 14b) indicates that the rainfall is slightly less at all latitudes during the EL Niño years than during the La Niña years. On the other hand, the central and eastern North Pacific maximum zonally averaged mean non-tropical cyclone rainfall (Fig. $14 \mathrm{~d}$ and f) are greater in the ITCZ region of the 
tropics (equatorial of $10^{\circ} \mathrm{N}$ ) and are located more equatorward for the El Niño years than during La Niña years. These findings are consistent with the global rainfall studies by Janowiak and Arkin, 1991, Druyan and Hastenrath, 1993 and Huffman, et. al. (1997), in that the total rainfall associated with the ITCZ is found more equatorward during the warm ENSO event than observed during the cool ENSO event. In the subtropical and middle latitudes of the majority of the North Pacific, the mean monthly non -tropical cyclone rainfall for the El Niño years is nearly similar to that of the La Niña years.

The western North Pacific zonally average mean tropical cyclone rainfall in Fig. 14a is greater at all latitudes during the El Niño years than during the La Niña years with maximum values located in the tropical latitudes $\left(10^{\circ}-20^{\circ}\right)$ that are approximately three times greater. It is also noted from the figure that the maximum zonally averaged mean tropical cyclone rainfall is located a little more equatorward during the El Niño years as compared to the La Niña years. These results are not consistent with the earlier ENSO findings by Chan (1985), Li 1988), Wu and Lau (1992), Ramage and Hori (1981), and Landers (1993).

However, Figs. $14 \mathrm{c}$ and e show, respectively, that the zonally averaged mean monthly central and eastern North Pacific tropical cyclone rainfall for the El Niño years is greater between $10^{\circ}-15^{\circ} \mathrm{N}$ and between $10^{\circ}-20^{\circ} \mathrm{N}$ than that for the La Niña years. Unlike the equatorial shift that was observed with the maximum non-tropical cyclone rainfall during the warm ENSO years in this study and from the maximum total rainfall observed in earlier studies by Janowiak and Arkin, 1991, Druyan and Hastenrath, 1993 and Huffman, et. al. (1997), there is little equatorial shift observed with the maximum zonally average mean monthly tropical cyclone rainfall in these regions. 
The tropical cyclone frequency and intensity data for the three El Niño/La Niña years (see Table 1), reveal that there are also a difference in the number and intensity of the North Pacific tropical cyclones between the warm and cool ENSO years. For example, the number of tropical cyclones at all stages of intensity is greater in all North Pacific Ocean basins during the El Niño years as compared to the same period during the La Niña years. In addition, Table 1 suggests that the tropical cyclones are more intense in all ocean basins of the North Pacific during the EI Niño years as compared to the same period during the Lal Niña years. These western North Pacific tropical cyclone statistics for this study are contrary to the findings of Chan (1985), Li 1988), Wu and Lau (1992), Ramage and Hori (1981), and Lander (1993), but are consistent with Lander (1993) results for the central and eastern North Pacific.

Table 1. The total number of tropical cyclones and tropical cyclones of depression, storm, and moderate (Vmax 32-64 $\mathrm{ms}^{-1}$ ) and strong (Vmax > $65 \mathrm{~ms}^{-1}$ ) typhoon/hurricane intensity observed from all available SSM/Is in the western, central, and eastern North Pacific during July-November of the El Niño and La Niña years.

$\begin{array}{lccc} & \text { North Pacific EI Niño/La Niña Years } & \\ & \text { Western } & \text { Central } & \text { Eastern } \\ \text { Depression } & 59 / 64 & 32 / 17 & 41 / 32 \\ \text { Storm } & 67 / 58 & 34 / 12 & 46 / 36 \\ \text { Moderate Typ/Hur } & 47 / 31 & 13 / 5 & 24 / 21 \\ \text { Strong Typ/Hur } & 17 / 6 & 3 / 0 & 5 / 1 \\ \text { All Trop Cyclones } & 190 / 159 & 82 / 34 & 116 / 90\end{array}$



FORCING

The synoptic scale environmental conditions that have been proposed to favor tropical cyclogenesis and intensification (e.g., tropical cyclone growth) are an atmosphere with minimum 850-200 mb vertical shear of less than $10 \mathrm{~ms}^{-1}$ (Reuter and Yau, 1986), strong large scale low-level (i.e., $850 \mathrm{mb}$ ) convergence of cyclonic vorticity (Riehl, 1954; Ooyama, 1964; Lee, 1986; Charner and Eliassen, 1964; Gray, 1979; Molinari and Scubis. 1985), and an ocean with a deep thermocline whose SSTs are above $26^{\circ} \mathrm{C}$ (Gray, 1979). Theoretical (Tuleya and Kurihara, 1982) and observational (Zehr, 1992) studies have shown that western North Pacific tropical cyclogenesis rarely occurs when SSTs are below $26^{\circ} \mathrm{C}$. Further, theoretical and observational studies by Emanuel (1986), Merrill (1988), Evans (1992), and DeMaria and Kaplan (1993) have demonstrated that the maximum intensity of a tropical cyclone is limited by SST to $29^{\circ} \mathrm{C}$. At SSTs above $29^{\circ} \mathrm{C}$, further intensification has not been observed. This limitation may be due to, perhaps, the decreased buoyancy in the eye wall region (Gray, 1995) or to the increased rain and spray and, therefore, reduced surface energy flux (Holland, 1995) as the tropical cyclone intensifies.

To assess why the El Niño years have more numerous, intense, and, therefore, wetter North Pacific tropical cyclones as compared to the La Niña years, the mean September (i.e., peak month for the occurrence of North Pacific tropical cyclones) tropospheric diagnostic parameters and SSTs are compared with the tropical cyclone rainfall for one of the couplet years (i.e., 87 El Niño/88 La Niño years). Fig. 15 displays the tropical cyclone rainfall difference for the two years. Fig. 16 shows the $850 \mathrm{mb}$ streamlines and the regions (shaded areas) of preferred North Pacific environmental parameters (minimum 850-200 mb vertical shear of less than $10 \mathrm{~ms}^{-1}$, convergence of 
lower-tropospheric cyclonic vorticity, and SSTs at $26^{\circ} \mathrm{C}$ or above) that favor tropical cyclone growth for September 1987 and 1988. These environmental parameters that favor tropical cyclone growth will be referred in the remaining part of the paper as "tropical cyclone growth parameters".

By comparing the mean $850 \mathrm{mb}$ streamline analysis with the tropical cyclone growth parameters of the two years (Fig. 16), it appears that the $850 \mathrm{mb}$ mean circulation and the environmental conditions that favor tropical cyclone growth are different. For example, in the tropical regions of the western and central North Pacific (i.e., equatorward of $20^{\circ} \mathrm{N}$ ) the mean $850 \mathrm{mb}$ circulation pattern during September, 1987 delineates a westerly flow. Poleward of this region, an elongated cyclonic circulation that is associated with the monsoon trough extends eastward from the Philippine Islands to the international dateline. The main areas of tropical cyclone growth parameters are associated with the monsoon trough, although the mean western and central North Pacific 850-200 mb vertical wind shear (figure not shown) is stronger during September, 1987 as compared to the September, 1988. However, during September, 1988 the western and central North Pacific mean $850 \mathrm{mb}$ monsoon trough and the westerlies that are observed equatorward of the trough during September, 1987 are replaced by a single cyclonic vortex center near the Philippine Islands and an east to southeasterly flow east of the vortex. The SST difference field (Fig. 17) indicates that the increase in tropical cyclone rainfall in 1987 in the western North Pacific occurred despite a cooling.

Even though the western and parts of the central North Pacific region (i.e.. equatorward of $20^{\circ} \mathrm{N}$ and $100^{\circ}-160^{\circ} \mathrm{E}$ ) experiences slightly cooler SSTs (but still warmer then the critical value of $26^{\circ} \mathrm{C}$ ) and stronger vertical wind shear during the El Niño year of 1987 as compared to the La Niña year of 1988, the areal extent of the tropical cyclone growth parameters increases in both of these regions. It appears that the presence of the 
monsoon trough with its stronger lower-tropospheric horizontal convergence of cyclonic vorticity are the main forcing mechanisms to favor the development of the wetter (Figs. 14 and 15) and more frequent and intense (Table 1) western and western central North Pacific tropical cyclones during the El Niño year of 1987 and not necessarily the change in SSTs. However, if significant warming of the SSTs (i.e., $>1.0^{\circ} \mathrm{C}$ ) does occur in the areas where the other tropical cyclone growth parameters exist, the enhanced ocean energy flux may further augment the growth of the tropical cyclone. These results are consistent with some of the earlier observations by Landers (1993).

Over the eastern North Pacific (i.e., equatorward of $20^{\circ} \mathrm{N}$ and $140^{\circ}-80^{\circ} \mathrm{W}$ ), Fig. 16 indicates that, like the western North Pacific, there is a slight difference between the location and areal extent of the mean September tropical cyclone growth parameters and the $850 \mathrm{mb}$ circulation patterns during the 1987 El Niño year as compared to that of the 1988 La Niña year. For example, the easterly flow observed off the coast of Baja California and Mexico during the 1987 El Niño year is replaced by double cyclonic vortices and a single anticyclonic vortex during $1988 \mathrm{La}$ Niña year. The $850 \mathrm{mb}$ circulation during the $1988 \mathrm{La}$ Niña year appears to reduce the areal extent of the tropical cyclone growth parameters as compared to that observed during the 1987 El Niño year. However, unlike the western North Pacific, Fig. 17 indicates that the SSTs during the 1987 El Niño year are significantly warmer in the tropical and eastern regions of the eastern North Pacific as compared to that during the 1988 La Niña year.

The differences between the 1987 and 1988 eastern North Pacific tropical cyclone growth parameters and the tropical cyclone rainfall are more related to warmer SSTs than the change in the $850 \mathrm{mb}$ circulation surrounding the tropical cyclones. This SST difference also suggests that the significantly warmer SSTs help augment tropical cyclone growth when the low vertical wind shear and the convergence of low-tropospheric cyclonic 
vorticity are collocated with the warm SST anomalies. For example, these warmer SSTs during the 1997 El Niño did not necessarily form Hurricane Linda (12 September, 1997) but it, most likely, helped intensify hurricane Linda to super hurricane status with the maximum wind speed near 225 miles $^{-1}$.

Unlike the tropical cyclone rainfall, the non-tropical cyclone rainfall is more profoundly influenced by SST variations. For example, the cooler SSTs within the majority of the western North Pacific had an adverse affect on the non-tropical cyclone rainfall by reducing the ocean energy flux, while in the ITCZ regions of the central and eastern North Pacific the large increase of SSTs had an enhancing affect by increasing the ocean energy flux during the El Niño years.

\section{Conclusions and Summary}

Rainfall estimates made from satellite passive microwave (SSM/I) observations are used to estimate the North Pacific monthly rainfall amounts contributed by tropical cyclones that became depression intensity and greater. These rainfall estimates from 1987-1998 were used to assess the impact of tropical cyclone rainfall on the geographical, seasonal. and the inter-annual distribution of total rainfall.

The main results of this study suggest the following.

1) Tropical cyclones contribute $7 \%$ of the rainfall to the entire domain of the North Pacific during the tropical cyclone season and $12 \%, 3 \%$, and $4 \%$ when the study area is limited to, respectively, the western, central, and eastern third of the ocean. The greatest contribution of tropical cyclone rainfall to the total rainfall are found east of the Philippine Islands $(30 \%)$ and west of the Mexican coast $(40 \%)$. Thus, it appears that 
tropical cyclone rainfall can greatly augment the seasonal rainfall during the growing season in some regions of the North Pacific and be a significant source of water for agricultural and other purposes.

2) The maximum zonally averaged tropical cyclone rainfall in all three basins of the North Pacific is located poleward of the maximum zonally averaged non-tropical cyclone rainfall. Because of the enhanced energy flux provided by warmer SSTs and the maturity of the monsoon trough during the late summer and fall months, the greatest amount of North Pacific tropical cyclone rainfall usually occur during this time.

3) The greatest amount of rainfall in the subtropical regions of the western North Pacific is mainly provided by typhoons, while the greatest amount of rainfall in the subtropical regions of the central and eastern North Pacific is mainly provided, respectively by depressions and storms. The greatest amount of rainfall in the mid-latitudinal regions of the North Pacific is provided by typhoons of the western North Pacific. The probable reasons for this is that the western North Pacific tropical cyclones have the greatest tendency to recurve to higher latitudes due to the mean eastward positioning of the North Pacific mid-tropospheric subtropical anticyclone. Also, the typhoons are usually wetter and are able to preserve their rainfall structure for a longer time as compared to weaker systems.

4) The couplet El Niño/La Niña years of 1987/1988, 1994/1995, and 1997/1998 show distinct differences between the El Niño and La Niña in both the tropical cyclone rainfall and the non-tropical cyclone rainfall variations. In the eastern North Pacific both the tropical cyclone and non-tropical cyclone rainfall increase during the El Niño and decrease during the La Niña years. In the western North Pacific during the El Niño the non-tropical cyclone rainfall, decreases, especially over the far western areas. The tropical 
cyclone rainfall, on the other hand, increases during the El Niño in the subtropical regions, especially east of the Philippine Islands, which shifts northward and eastward towards the dateline.

5) The changes of the patterns of the non-tropical cyclone rainfall across the North Pacific are mainly related to the SST variation. However, the increase of tropical cyclone rainfall during the El Niño years in the western North Pacific and parts of the central North Pacific appears to be related to the presence and eastward extension of the lower-tropospheric monsoon trough and not SSTs changes, which are usually negative in this region. The increase of tropical cyclone rainfall in the eastern North Pacific, like the increase of non-tropical cyclone rainfall, is related to the warmer SSTs during the El Niño years.

6) Finally, in response to the increase in non-tropical cyclone rainfall in the eastern North Pacific ITCZ region and, to a lesser extent, the increase in the western and eastern North Pacific tropical cyclone rainfall during the EL Niño years, it appears that large atmospheric circulation variations that are associated with these warm ENSO events have a significant role in altering the positioning of the large scale motions of the earth's atmosphere (i.e., Hadley, Walker circulation). These results are consistent with earlier ENSO studies.

Acknowledgments. Funding support was provided by the NASA Office of Earth Science Enterprise and (\#912-622-28-06-25). The authors would like to thank Dr. Ramesh Kakar of NASA Headquarters for his support of this work. 


\section{REFERENCES}

Adler, R. F., H.-Y. M. Yea, N. Prasad, W-K. Tao, and J. Simpson, 1991: Microwave simulations of a tropical rainfall system with a three-dimensional cloud model. J. Appl. Meteor, 30, 924-953.

Adler, R. F., G. J. Huffman, and P. R. Keehn, 1994: Global tropical rain estimates from microwave-adjusted geosynchronous IR data. Remote Sensing Reviews, 11, 125-152.

Barnston, A. G., and C. F. Ropelewski, 1992: Prediction of ENSO episodes using canonical correlation analysis. J. Climate, 7, 1316-1345.

Bell, T. L., P. K. Kunda, and C. Kummerow, 1996: Sampling errors of satellite estimates of gridded rainfall. Preprints. 13th Conf. on Probability and Statistics in the Atmospheric Science. San Francisco, Calif. Amer. Meteor. Soc., 298-300.

Berg, W. and S. K. Avery, 1994: Rainfall variability over the tropical Pacific from July 1987 through December 1991 as inferred via monthly estimates from SSM/I. J. of $A p p l$. Meteor. 33, 1468-1485.

Chan, J. C. L., 1985: Tropical cyclone activity in the northwest Pacific in relation to the El Niño/Southern Oscillation phenomenon. Mon Wea.. Rev., 113, 599-606.

Charney, J. G., and A. Eliassen, 1964: On the growth of the hurricane depression. J. Atmos. Sci., 21, 68-75.

DeMaria, M , and J. Kaplan, 1993: Sea surface temperature and the maximum intensity of Atlantic tropical cyclones. J. of Climate, 6, 1324-1334. 
Druyan, L. M., and S. Hastenrath, 1993: tropical impacts of SST forcing: A Case Study for 1987 versus $1988, J$ of Climate, $7,1316-1323$.

Emanuel, R. A., 1986: An air-sea interaction theory for tropical cyclones. Part 1: Steadystate maintenance. J. Atmos. Sci., 43, 585-604.

Evans, J. L., 1992: Sensitivity of tropical cyclone intensity to sea surface temperature. $J$. of Climate, 6, $1135-1140$.

Gray, W. M., 1979: Hurricanes. Their formation, structure, and likely role in the tropical circulation. Meteorology over the Tropical Oceans, D. F. Shaw, Ed. Roy. Meteor. Soc., $155-218$

Gray, W. M., 1995: Limiting influence on the maximum intensity of tropical cyclones. 21st Conf. on Hurricanes and Tropical Meteorology, Miami, Fla., Amer. Meteor. Soc., $368-370$.

Holland, G. J., 1995: A thermodynamic approach to determining the maximum potential intensity of tropical cyclones. 2lst Conf. on Hurricanes and Tropical Meteorology, Miami, Fla., Amer. Meteor. Soc., 359-361.

Holiday, C. R. and A. H. Thompson, 1979: Climatological characteristics of rapidly intensifying typhoon, Mon. Wea. Rev., 10, 1022-1034.

Hollinger, J, T., 1991: DMSP Special Sensor Microwave/Imager calibration/validation final report. Vol. 11. Naval Research Laboratory, 12-25 pp. 
Huffman, G. J., R. F. Adler, B. Rudolf, U. Schneider, and P. R. Keehn, 1995: Global precipitation estimates based on a technique for combining satellite-based estimates, rain gauge analysis, and NWP model precipitation information. J. of Climate, 8, 1284-1295.

Huffman, G. J., R. F. Adler, P. Arkin, A. Chang, R. Ferraro, A. Gruber, J Janowiak, A. McNab, B. Rudolf, and U. Schneider, 1997: The global precipitation climatology project (GPCP) combined precipitation dataset. Bull. Amer. Meteor. Soc., 78, 5-20.

Janowiak, J. E., and P. A. Arkin, 1991: Rainfall variations in the tropics during 19861989, as estimated from observations of cloud top temperatures. J Geophy. Res.. 96. $3669-3674$.

Lander, M. A. 1993: An exploratory analysis of the relationship between tropical storm formation in the western North Pacific and ENSO. Mon. Wea. Rev., 122, 636-651.

Laughlin, C. R., 1981: On the effort of temporal sampling on the observation of mean rainfall. Precipitation measurement from space, Atlas, D. and O. Thiele, editors, avialable from NASA/GSFC Greenbelt, MD. 20771.

Lee, C. S., 1986: An observational study of tropical cloud cluster evolution and cyclogenesis in the Western North Pacific. Colorado State University, Atmospheric Science Paper 403, 250 pp.

Li, C., 1988: Actions of typhoon over the western Pacific (including the South China Sea) and El Niño. Adv. Atmos. Sci., 5, 107-113. 
Merrill, R. T., 1988: Environmental influence on hurricane intensification. J. Atmos. Sci., 45, $1678-1687$.

Molinari, J., and S. Skubis, 1985: Evolution of the surface wind field in a intensifying tropical cyclone., J. Atmos. Sci., 42, 2865-2879.

Ooyama, K. V., 1964: A dynamical model for the study of tropical cyclone development. Geofis. Int., 4, 187-198.

Ramage, C. S., and A. M. Hori, 1981: Meteorological aspects of El Nino. Mon. Wea. $R e^{\prime} v_{.}, 109,1827-1835$.

Reynolds, R. W. and T. S. Smith, 1994: Improved global sea surface temperature analyses. J. Climate, 5, 929-948.

Riehl, H. 1954: Tropical Meteorology, McGraw-Hill, 392 pp.

Rodgers, E. B., S. W. Chang, and H. F. Pierce, 1994: A satellite-observational and numerical study of precipitation characteristics in western North Atlantic tropical cyclones. J. Appl. Meteor., 33, 129-139.

Rodgers, E. B. and H. F. Pierce, 1995: A satellite-observational study of precipitation characteristics in western North Pacific tropical cyclones. J. Appl. Meteor., 34, 25872599.

Rueter, G. W., and M. K. Yau, 1986: Numerical modeling of cloud development in a sheared environment. Bettr. Phys. Atmosph., 60, 65-80. 
Tuleya, R. E., and Y. Kurihara 1982: A note on the sea surface temperature sensitivity of a numerical model of tropical storm genesis. Mon. Wea. Rev., 119, 2063-2069.

Schubert, S. D., R. B. Rood, and J. Plaendiner, 1993: An assimilated dataset for earth science applications. Bul. of the Amer. Meteor. Soc, 74, 2331-2342.

Waliser, D. E., and C, Gauther, 1993: A Satellite-derived Climatology of the ITCZ. J. of Climate, 6, 2162-2174.

Wang, W. 1994: On the annual cycle in the tropical eastern Central Pacific. J. of Climate 7, 1926-1941.

Wu, G. and M-C Lau, 1992: A GCM simulation of the relationship between tropical-storm formation and ENSO. Mon. Wea. Rev., 120, 958-977.

Zehr, R. M., 1992: Tropical cyclogenesis in the western North Pacific. NOAA Tech. report NESDIS 61, $181 \mathrm{pp}$. 


\section{FIGURE CAPTIONS}

Fig. I A plan view showing the SSM/I-derived mean monthly rainfall amounts (mm month ${ }^{-1}$ ) contributed by non-tropical cyclone systems (upper panel) and tropical cyclones (middle panel), and the fractional amount (percentage) of rainfall contributed by the North Pacific tropical cyclones (lower panel) for the months of July-November 1987. June-November 1988-1989, and 1991-1998 (65 month period). Brown and blue background designate, respectively, non-raining land and oceans. The color bar code delineates the percentage and rainfall amounts above each figure.

Fig. 2 The SSM/I-derived $2.5^{\circ}$ latitudinal non-tropical cyclone and tropical cyclone zonally averaged mean monthly rainfall amounts $\left(\mathrm{mm} \mathrm{month}^{-1}\right.$ ) for, respectively, the (a and b) western, (c and d) central, and (e and f) eastern North Pacific for the 65 month period.

Fig. 3 A plan view showing the SSM/I-derived mean monthly tropical cyclone rainfall amounts (mm month ${ }^{-1}$ ) contributed by tropical cyclones for 1988, 1989, and 19911998 for the months of June-November. The white background designate non-raining land and oceans areas. The gray bar code delineates the rainfall amounts.

Fig. 4 A histogram showing the SSM/I-derived averaged mean monthly rainfall amounts (mm month ${ }^{-1}$ ) contributed by non-tropical cyclones systems (dark shade) and tropical cyclones (hatched shade) for 1988, 1989, and 1991-1998 during June-November for the (a) western, (b) central, and (c) eastern North Pacific. Percentage above the bar graph represents the percentage of rainfall contributed by tropical cyclones during the month. 
Fig. 5 The SSM/I-derived $2.5^{\circ}$ latitude zonally averaged mean monthly rainfall amounts (mm month ${ }^{-1}$ ) contributed by tropical cyclones for 1988, 1989, and 1991-1998 during the early summer (June-July), late summer (August-September), and fall (OctoberNovember) seasons for the (a) western, (b) central, and (c) eastern North Pacific.

Fig. 6 A plan view showing the SSM/I-derived mean monthly tropical cyclone rainfall amounts ( $\mathrm{mm}$ month $^{-1}$ ) contributed by tropical cyclones at depression, storm, and typhoon/hurricane stage during June-November of 1988, 1989, and 1991-1998. The white background designate non-raining land and oceans areas. The gray bar code delineates the rainfall amounts.

Fig 7 (a) A histogram showing the SSM/I-derived mean monthly rainfall amounts (mm month ${ }^{-1}$ ), percentage of contribution, and number of observations for the western (dark shade), central (light shade), and eastern (light hatched) North Pacific tropical cyclones at depression, storm, and typhoon/hurricane stage during the 65 month period and (b) the SSM/I-derived mean rain rates for western (dark shade), central (light shade), and eastern (light hatched) North Pacific typhoons/hurricanes within four $111 \mathrm{~km}$ wide annular areas surrounding the tropical cyclone center during the 65 month period.

Fig. 8 The SSM/l-derived $2.5^{\circ}$ latitudinal zonally averaged mean monthly rainfall amounts (mm month-1) contributed by the (a) western, (b) central, and (c) eastern North Pacific tropical cyclones of depression, storm, and typhoon/hurricane stage during the 65 months period.

Fig. 9 A plan view showing the SSM/I-derived mean monthly tropical cyclone rainfall anomalies (mm month ${ }^{-1}$ ) for the years of 1987-1989 and 1991-1998 during July- 
November period. White background designate non-raining land and oceans areas. The light and dark shades delineates, respectively, the positive and negative rainfall anomalies.

Fig. 10 A histogram showing the SSM/I-derived non-tropical cyclone (dark shade) and tropical cyclone (hatched shade) mean monthly rainfall amounts ( $\mathrm{mm} \mathrm{month}^{-1}$ ) for the (a) western, (b) central, and (c) eastern North Pacific during the July-November period for the years of 1987-1989 and 1991-1998. Percentage values indicate the fractional amount of rainfall contributed by tropical cyclones. "Es" and "Ls" represent, El Niño and La Niña years as defined by the Niño 3.4 SST anomalies.

Fig. 11 Time history of the SST anomalies $\left({ }^{\circ} \mathrm{C}\right)$ in the Niño 3.4 region from 1980 1999. Light (dark) shades represent positive (negative) SST anomalies.

Fig. 12 A scatter plot of the tropical eastern North Pacific SST anomalies in the 3.4 Niño region and the mean monthly rainfall amounts ( $\mathrm{mm}$ month $^{-1}$ ) contributed by tropical cyclones during July-November period for the years of 1987-1989, and 1991-1998 for the (a) western, (b) central, and (c) eastern North Pacific. The best-fit line (broad), the equation of the line, and the linear correlation coefficient are shown for each North Pacific ocean basin. Also shown are lines (thin) connecting the three EL Niño/La Niña couplets (i.e., 1987/1988, 1994/1995. and 1997/1998).

Fig.13 A plan view of the difference between the mean monthly rainfall amounts (mm month ${ }^{-1}$ ) contributed by the North Pacific non-tropical cyclone systems (top panel) and tropical cyclones (bottom panel) during El Niño years (1987, 1994, and 1997) minus the La Niña years (1988, 1995, and 1998). Brown and blue background designate. respectively, non-raining land and oceans areas. The color bar code delineates the rainfall differences. 
Fig. 14 The SSM/I-derived $2.5^{\circ}$ latitudinal zonally averaged mean monthly rainfall amounts (mm month ${ }^{-1}$ ) for the tropical cyclones and non-tropical cyclones, respectively, for the (a and b) western, ( $c$ and d) central, and (e and f) eastern North Pacific during the El Niño (solid lines) and La Niña years (dashed lines).

Fig. 15 A plan view of the difference between the mean monthly rainfall amounts $\left(\mathrm{mm}\right.$ month $^{-1}$ ) contributed by the North Pacific tropical cyclones during July-November of the 1987 El Niño year minus the 1988 La Niña year. Brown and blue background designate, respectively, non-raining land and oceans. The color bar code delineates the rainfall differences.

Fig. 16 A plan view of the mean monthly $850 \mathrm{mb}$ streamline field and the regions that contain the tropospheric dynamics and SSTs parameters (gray region) that are needed for tropical cyclone growth in the North Pacific during September, 1987 El Niño (top panel) and September, 1988 La Niña years (bottom panel).

Fig. 17 Plan view of the mean September, 1987 SST $\left({ }^{\circ}\right.$ C) minus the mean September, 1988 SST $\left({ }^{\circ} \mathrm{C}\right)$. The gray and white background deliniate, respectively, the positive and negative SST differences. 


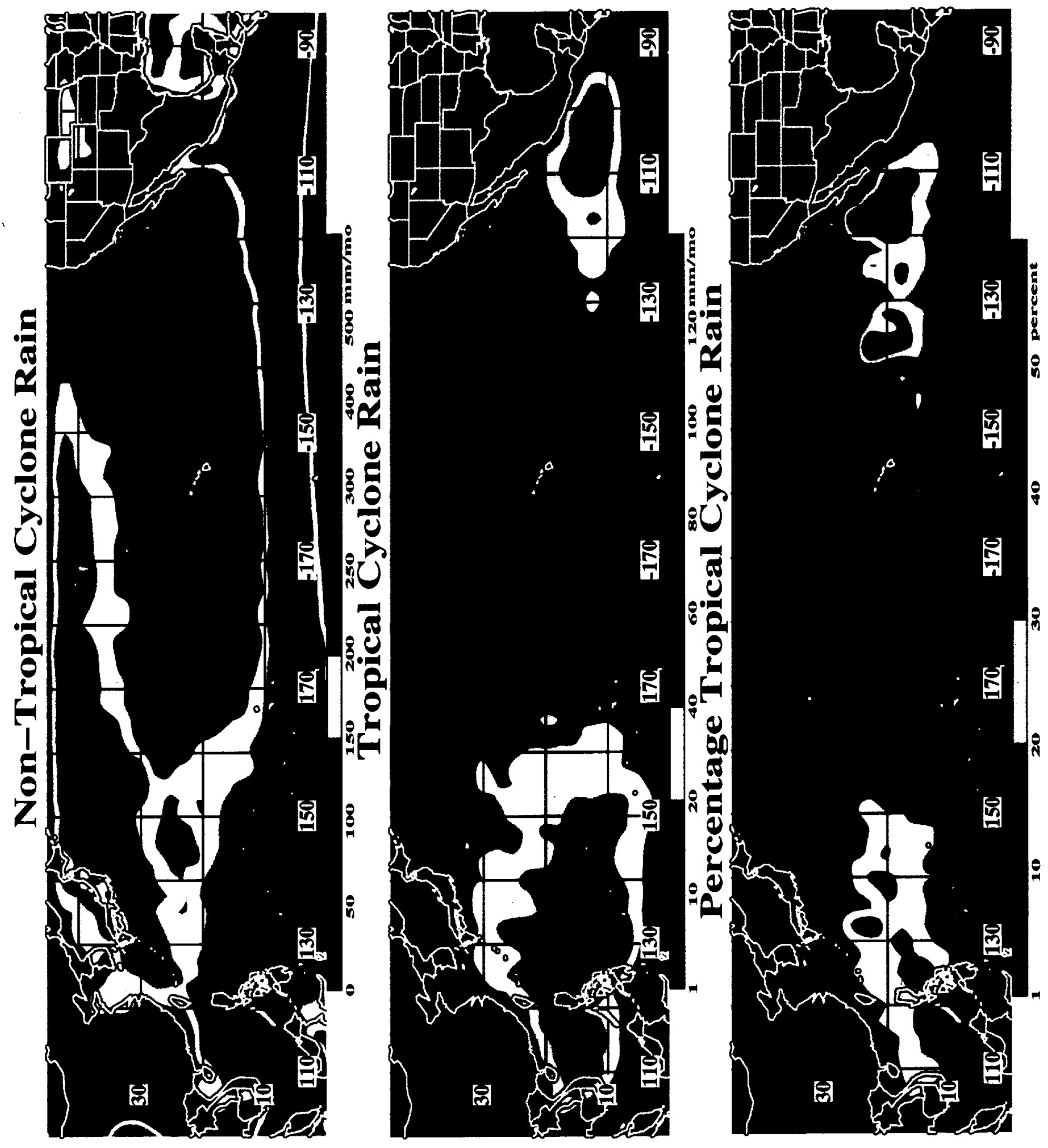



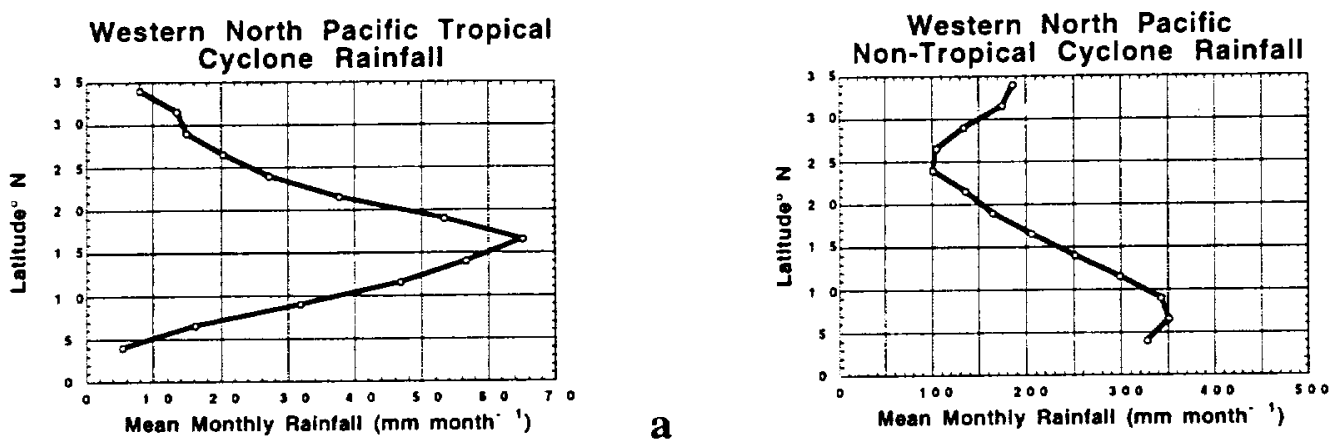

b
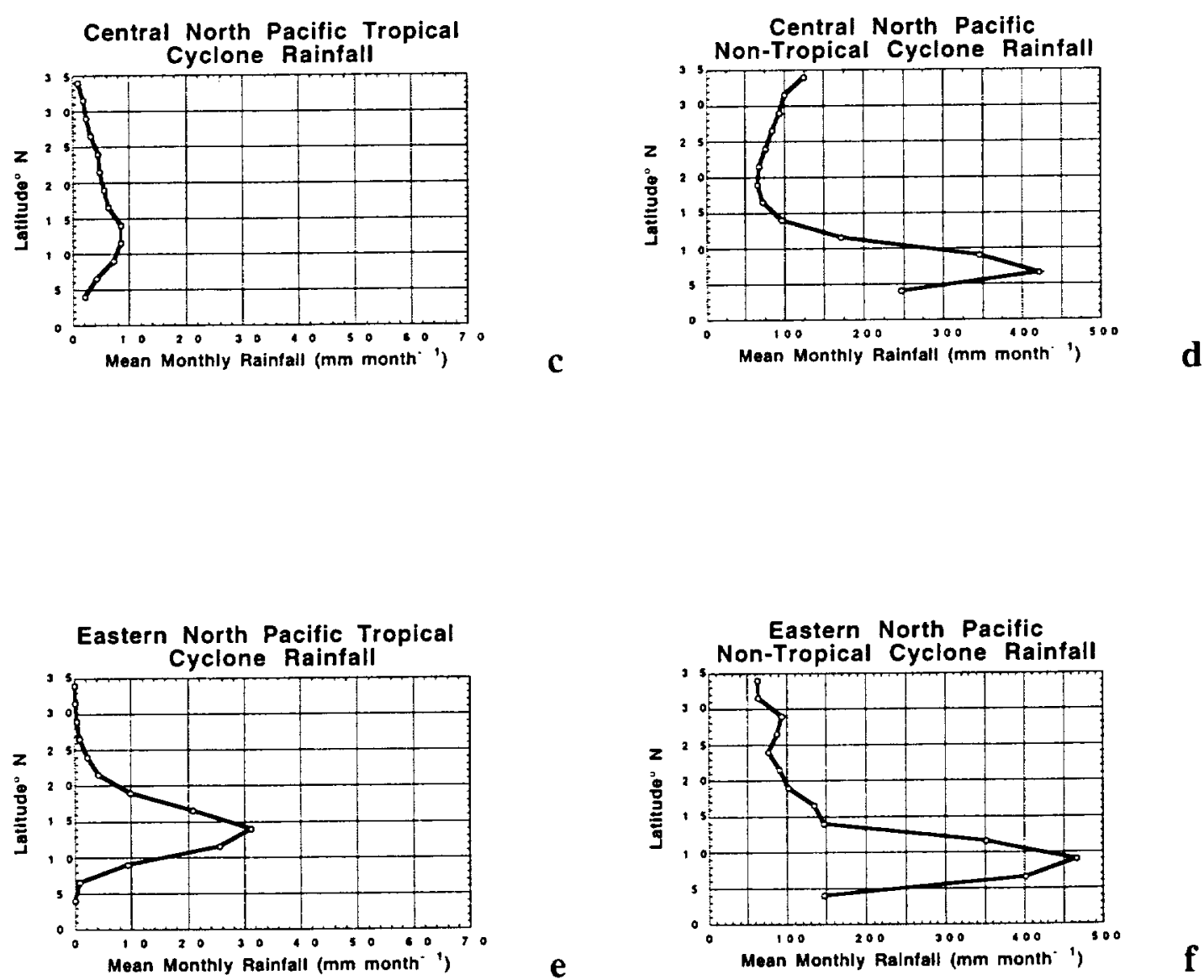

Fig. 2 


\section{Monthly Tropical Cyclone Rain}
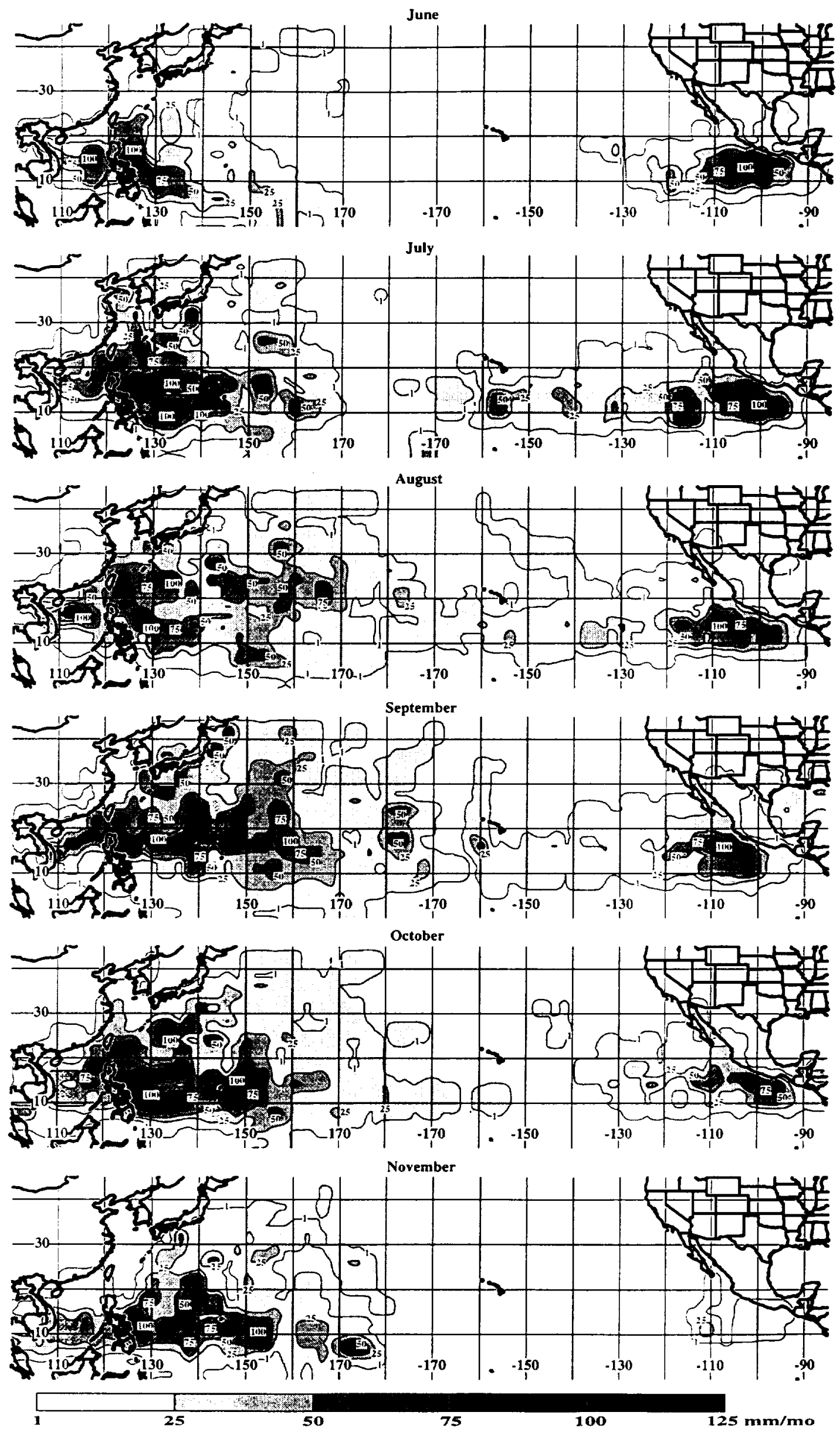


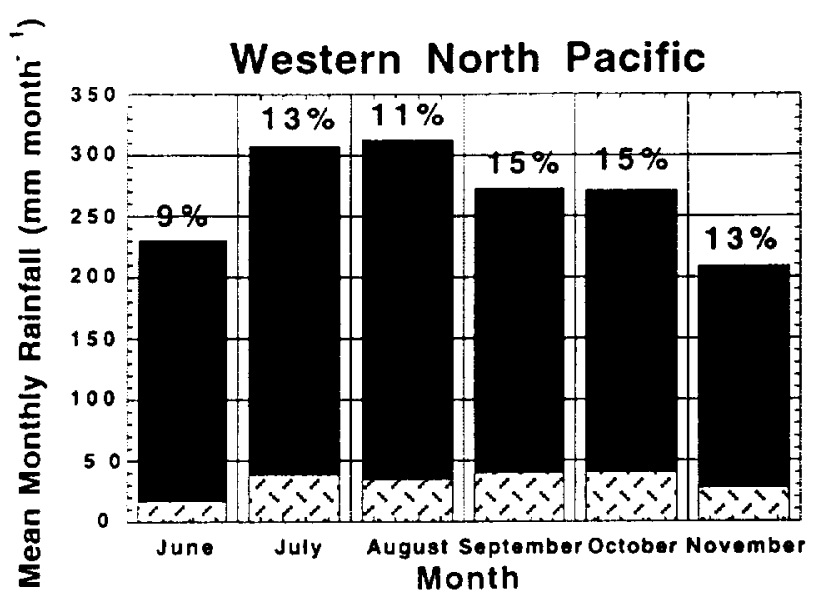

a
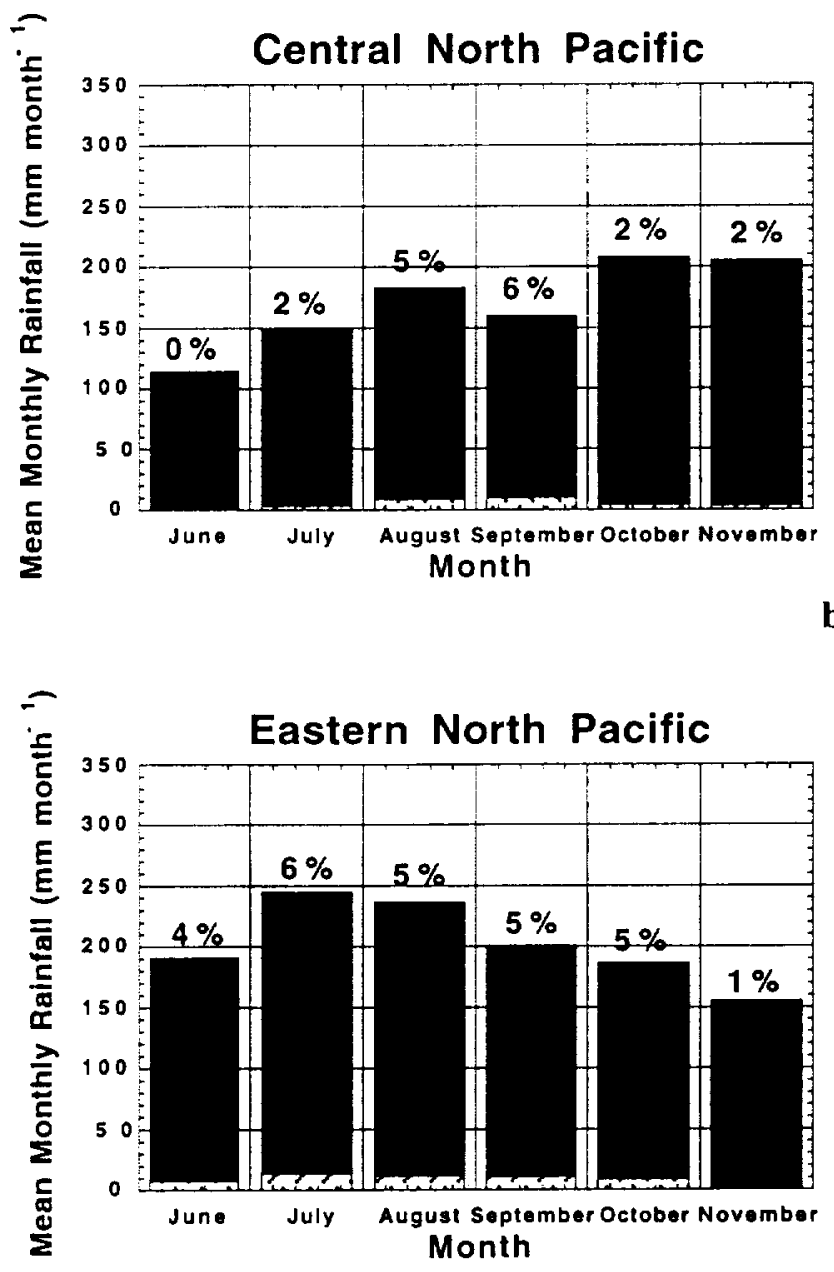

c

Fig. 4 


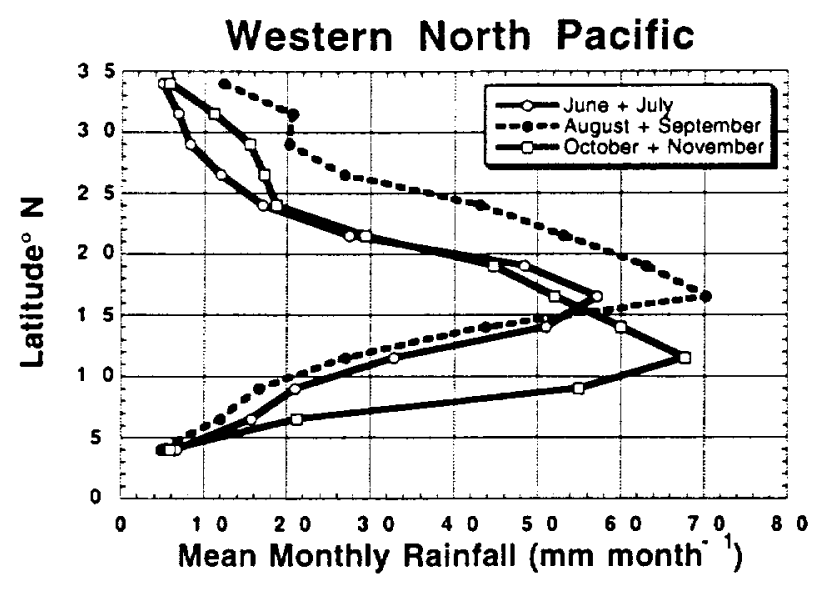

a
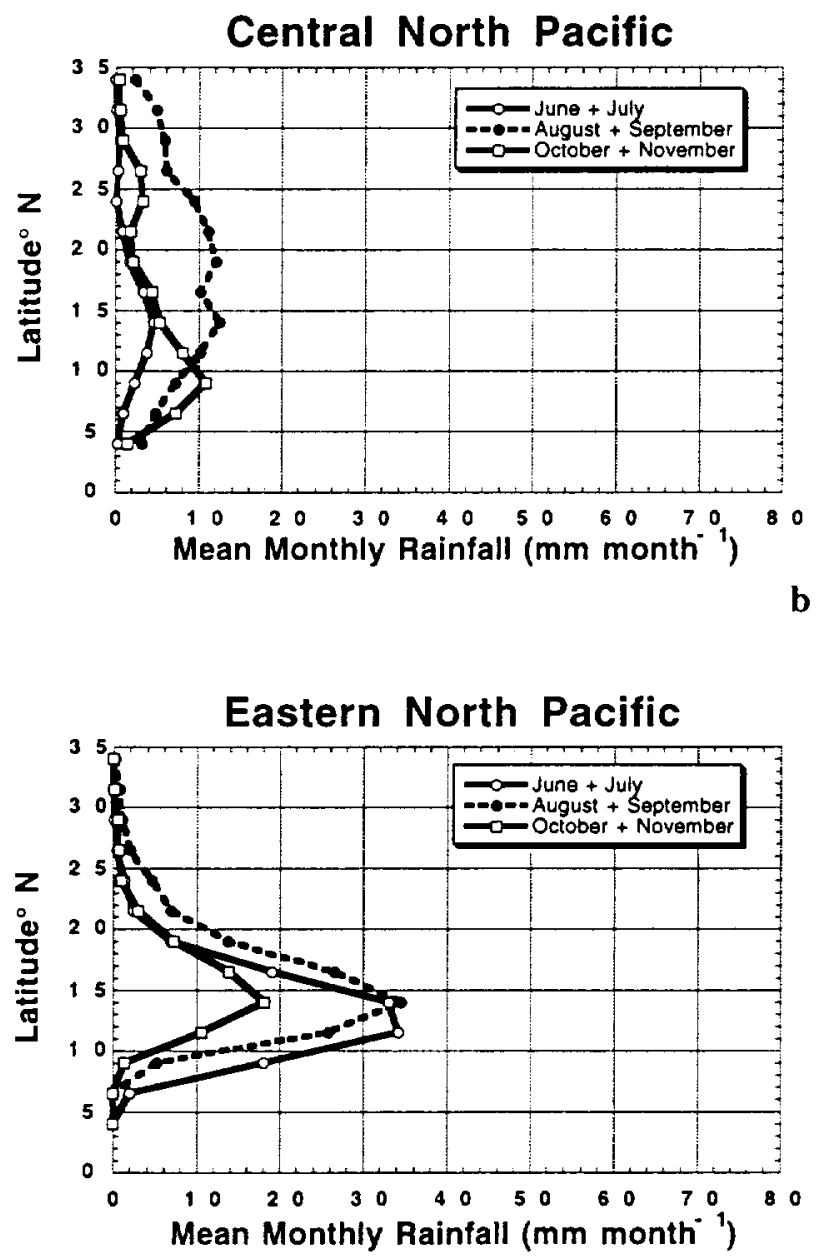

c Fig. 5 


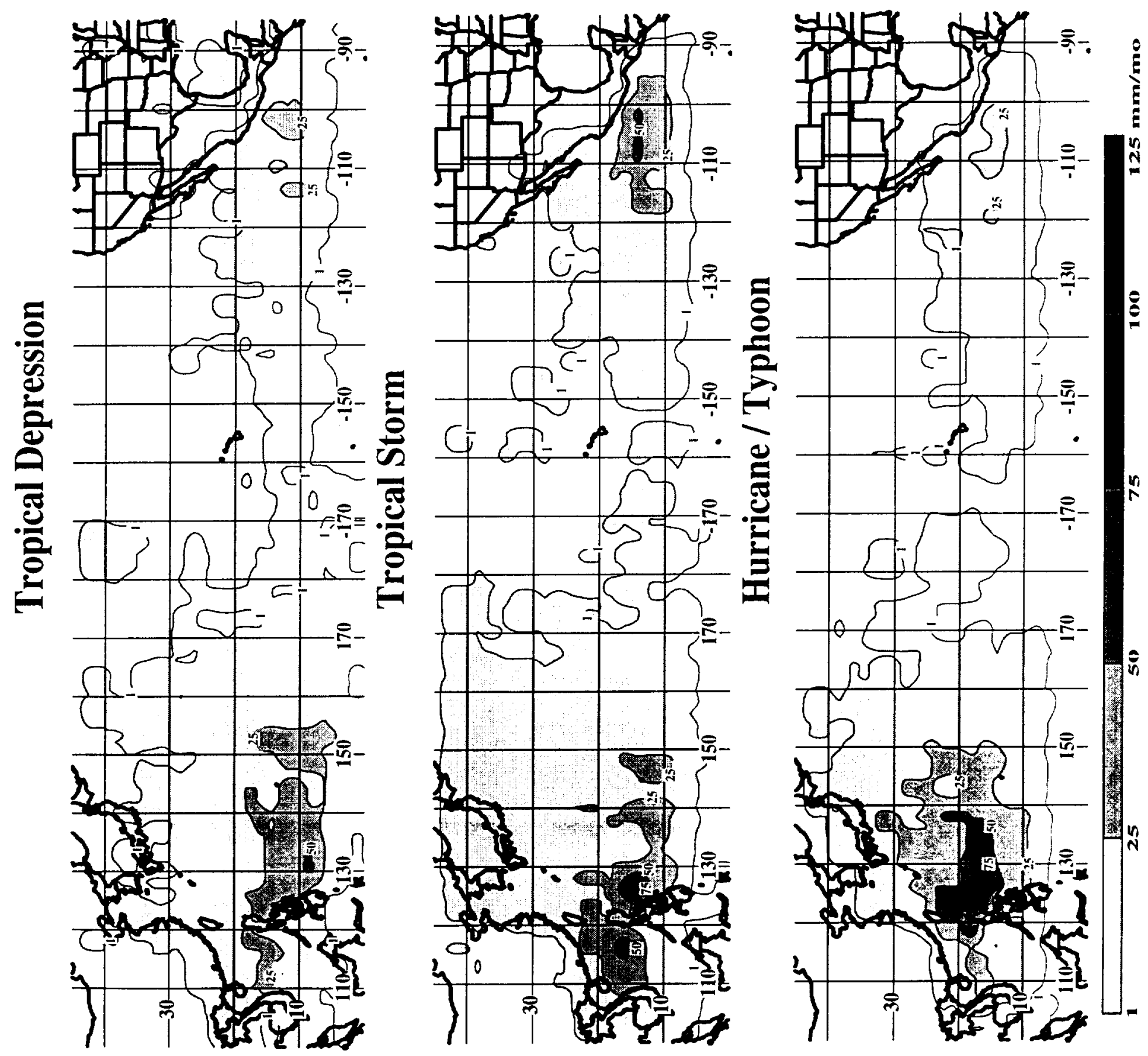




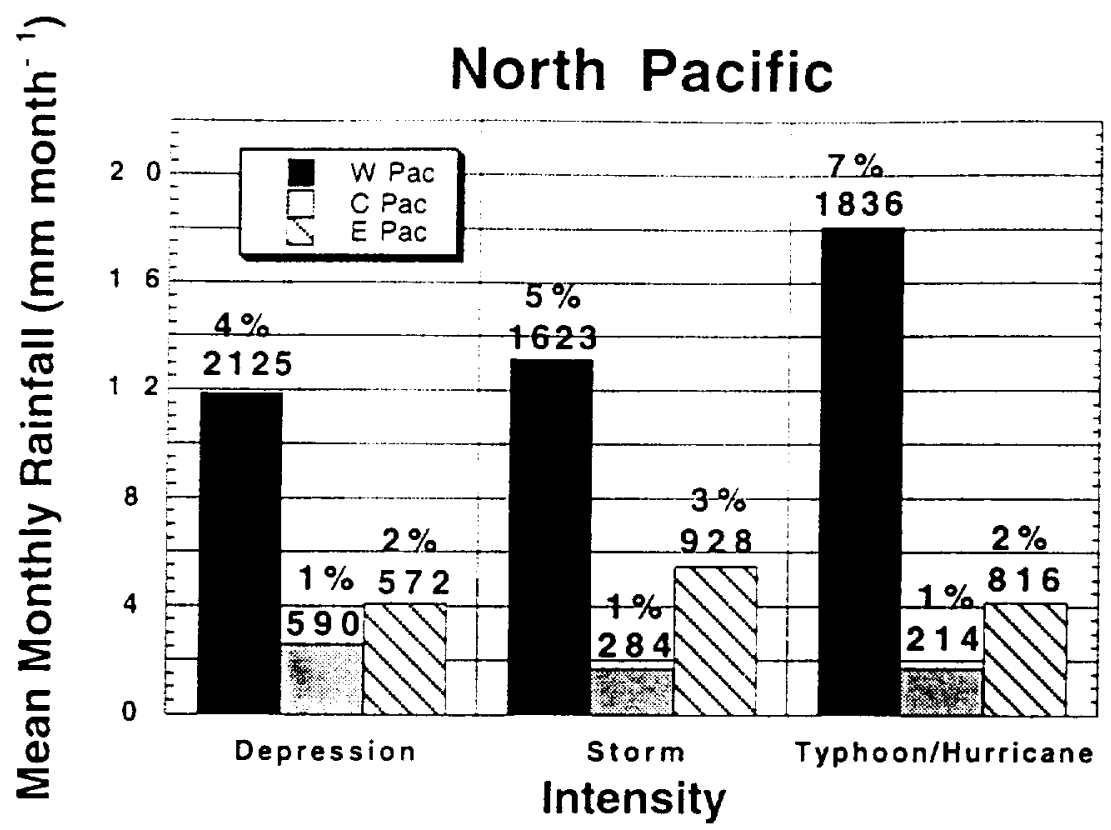

a

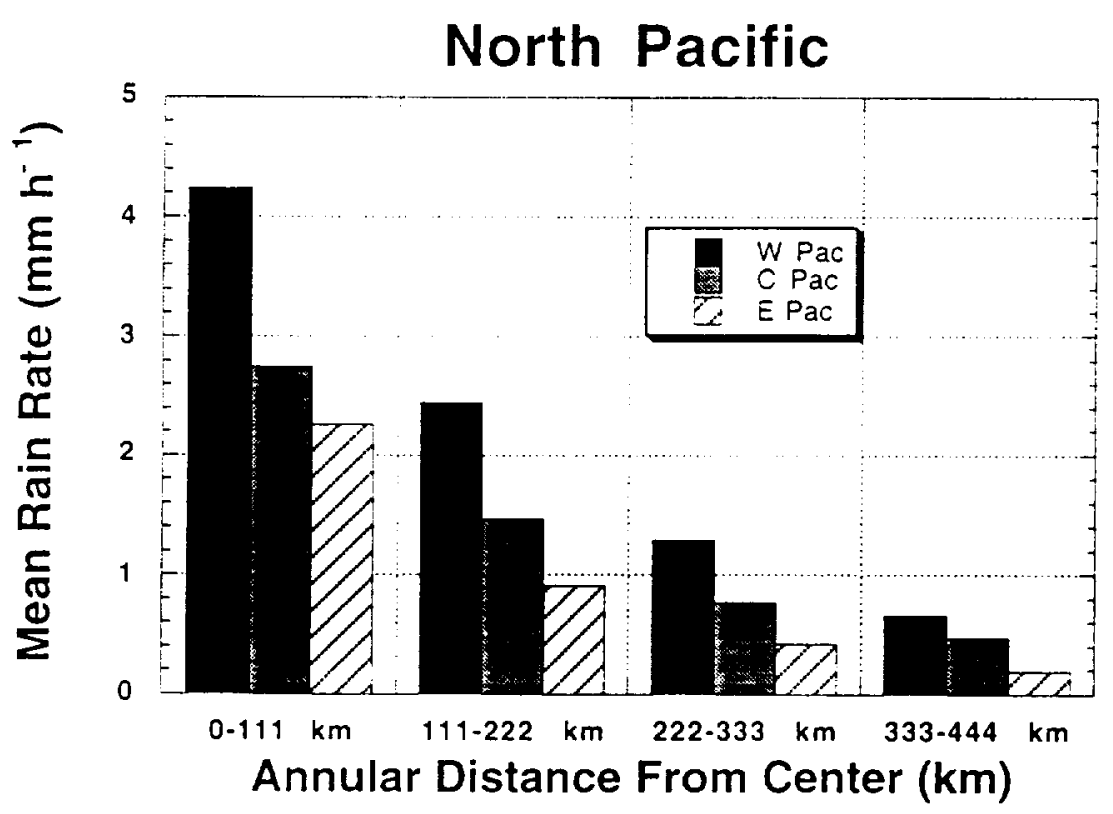

b

Fig. 7 

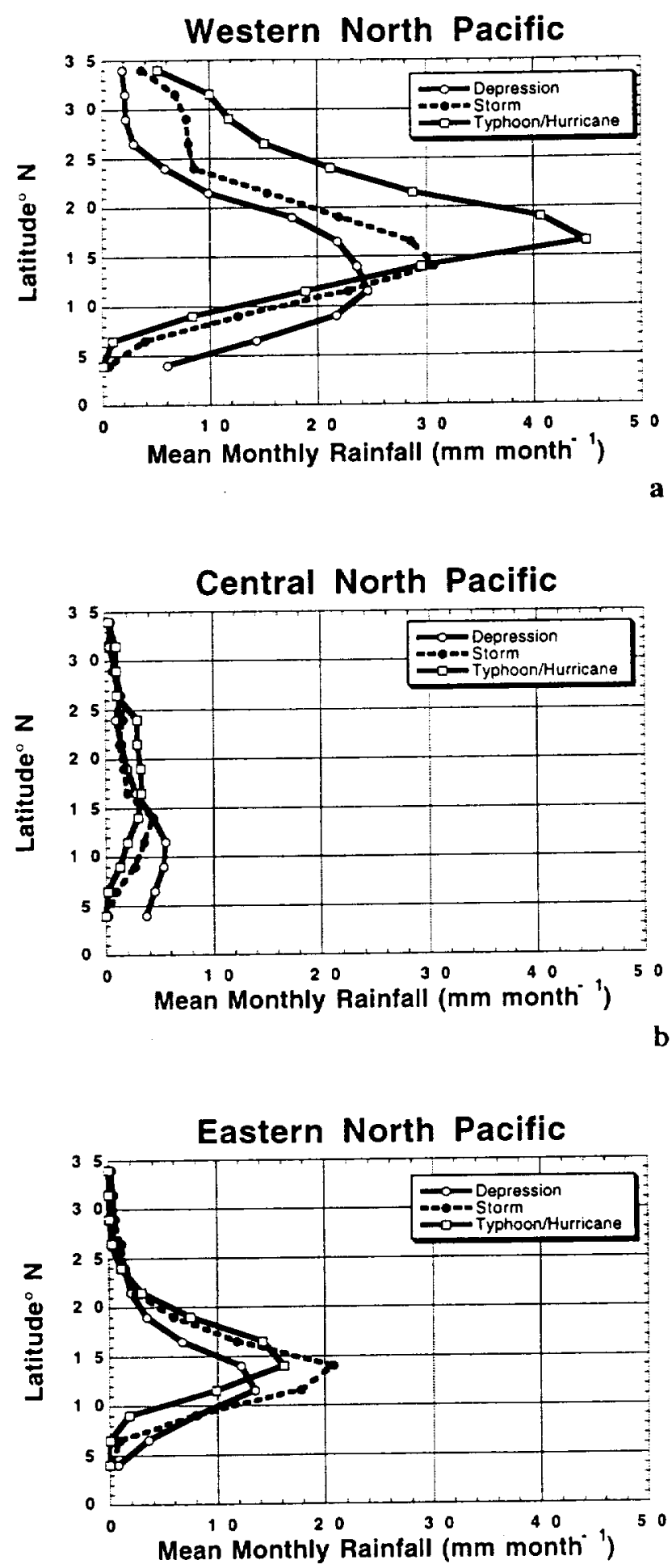

c Fig. 8 


\section{Semi-Annual Tropical Cyclone Rain Anomalies}

\section{7}

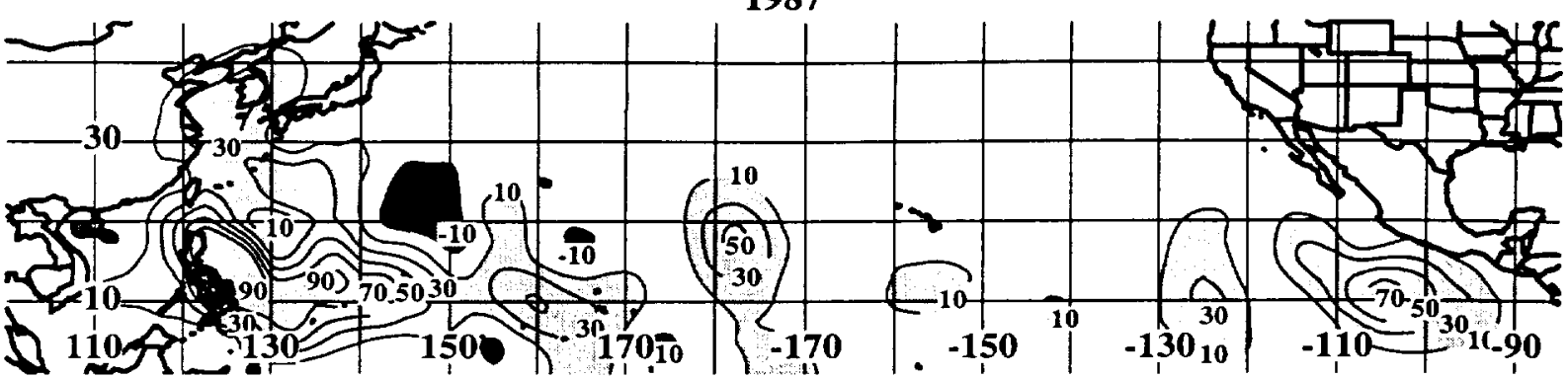

1988

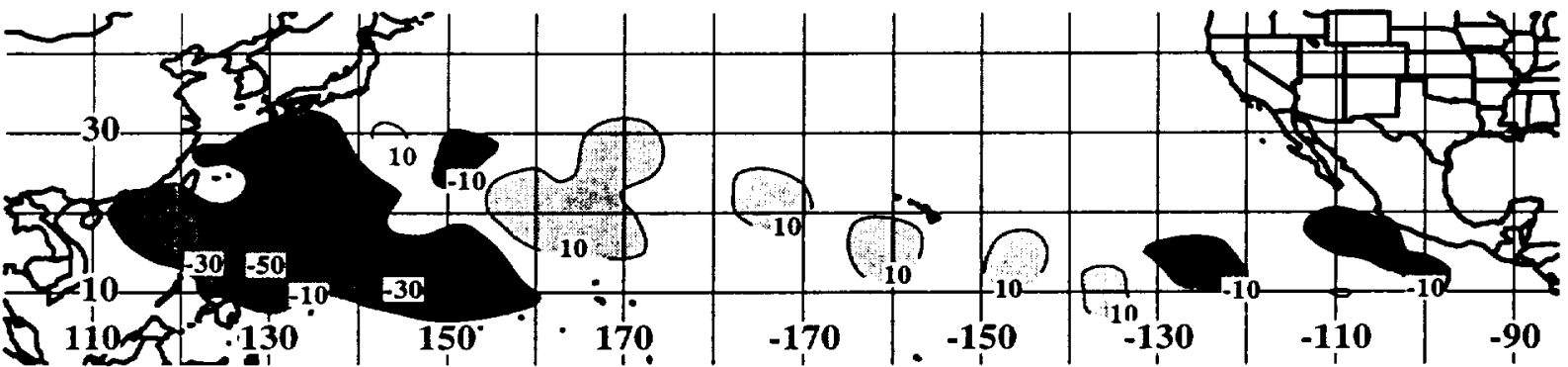

1989

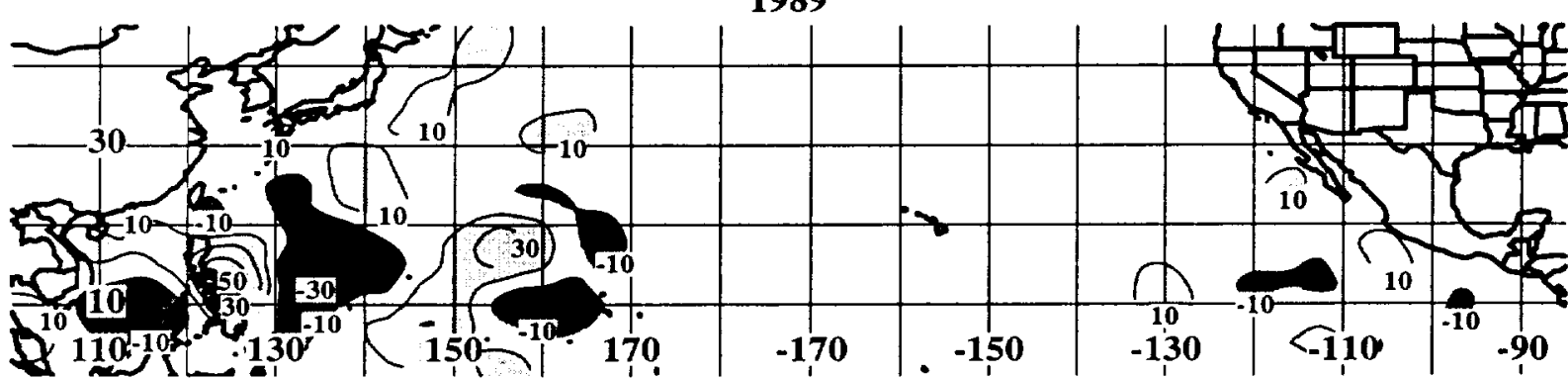

1991

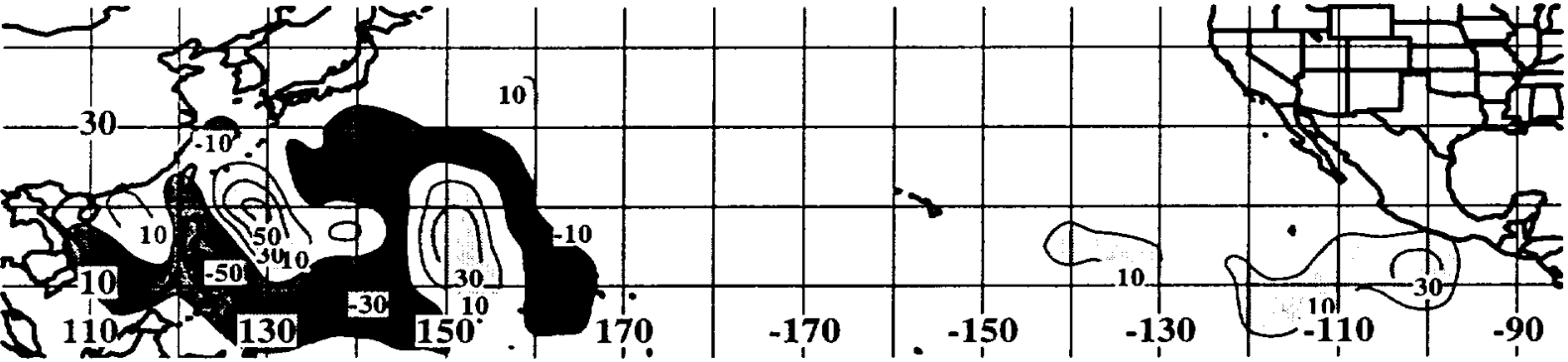

1992

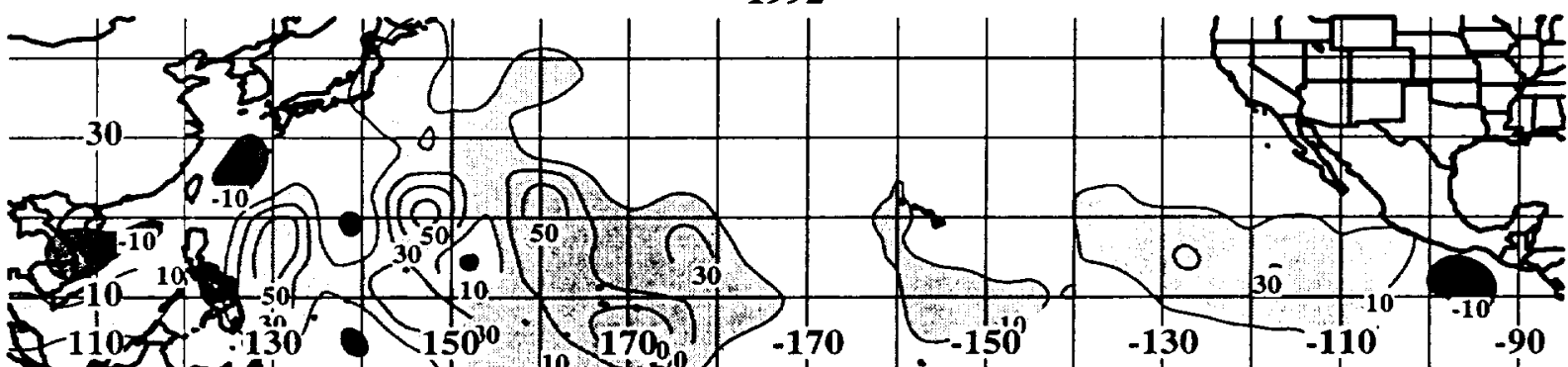

1993

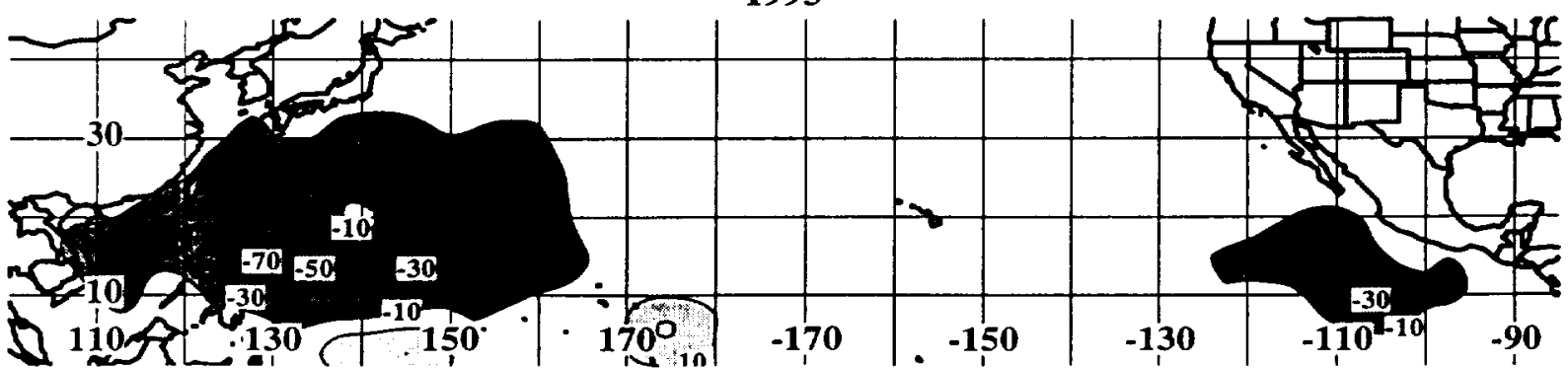


Semi-Annual Tropical Cyclone Rain Anomalies

1994

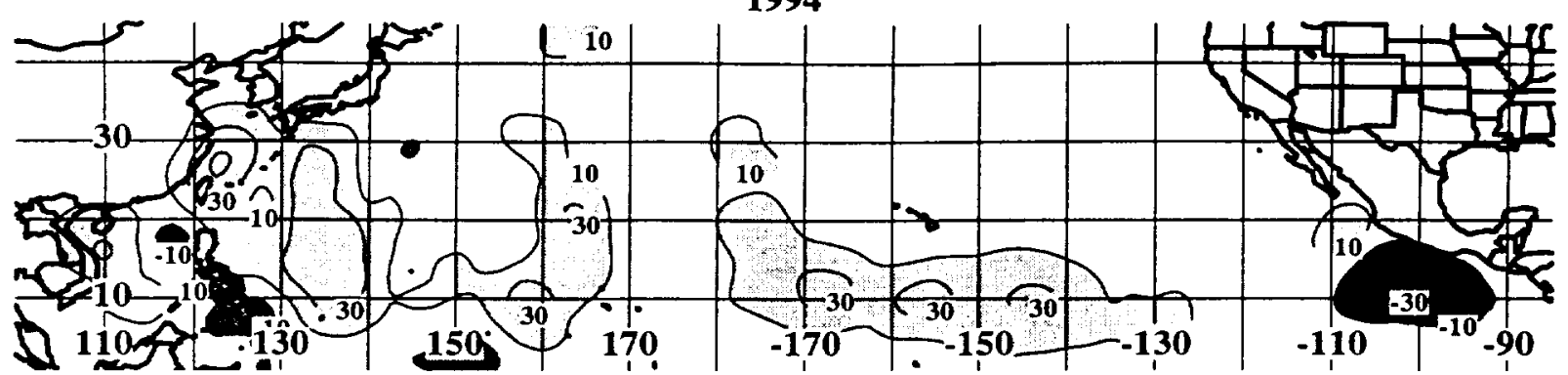

1995

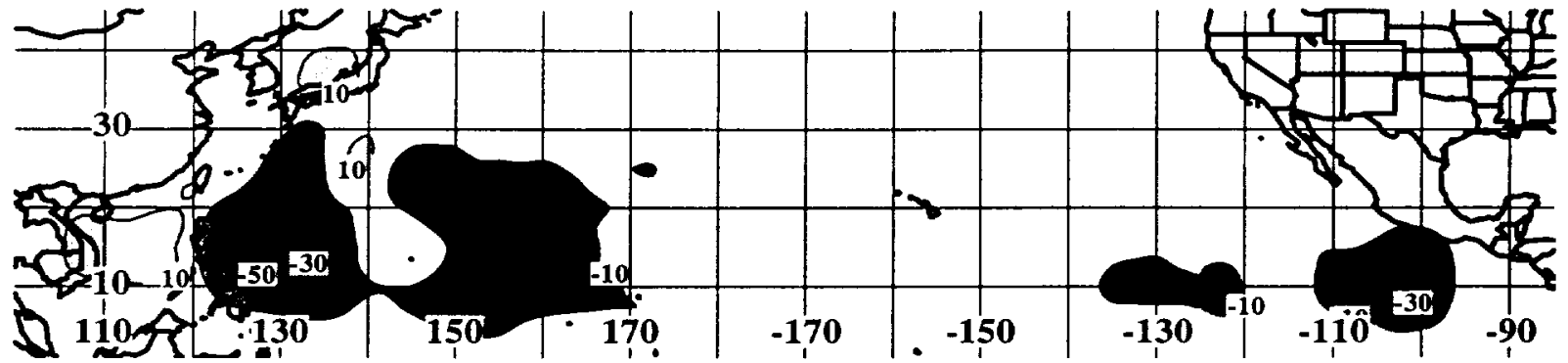

1996

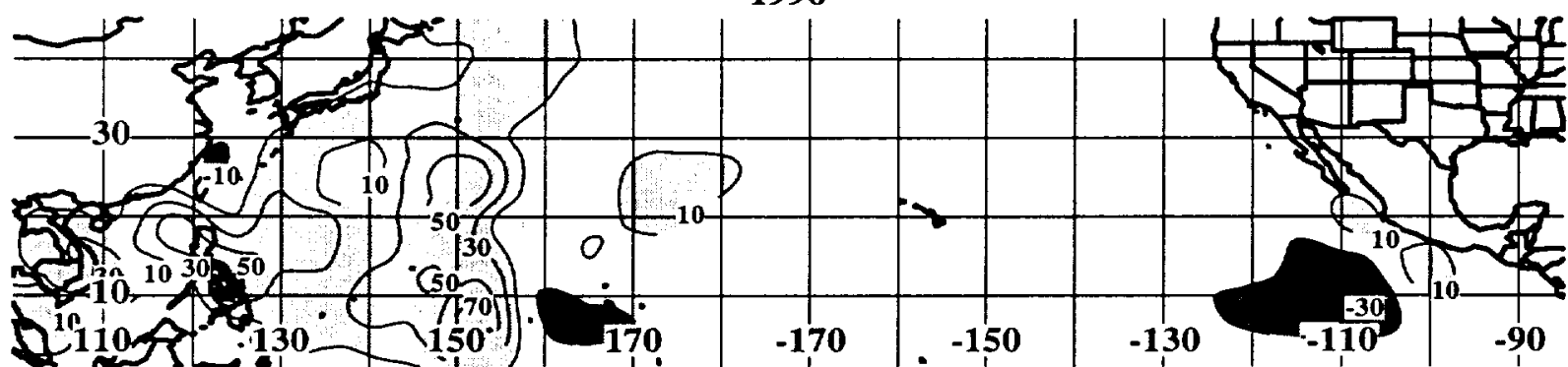

1997

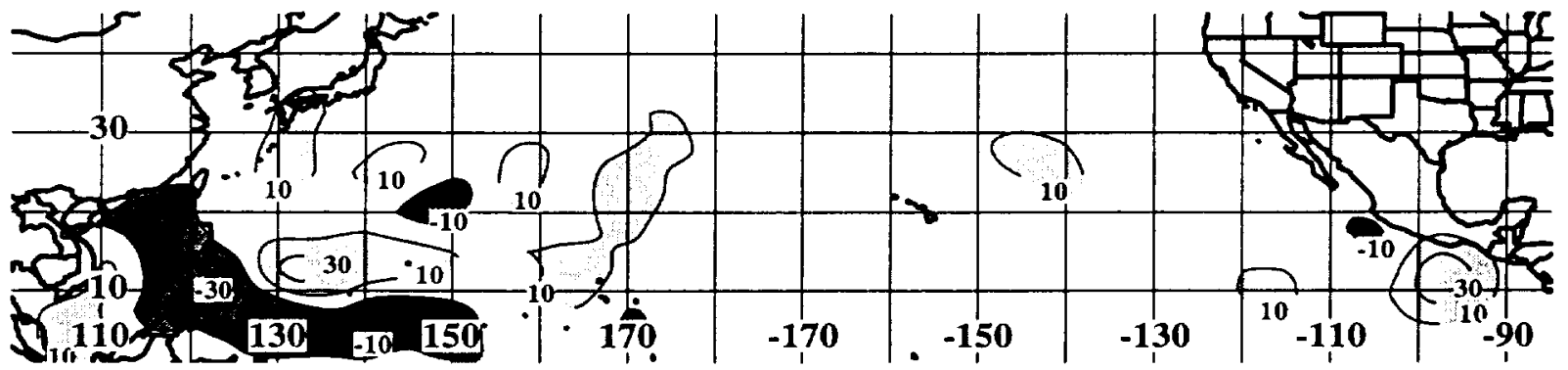

1998

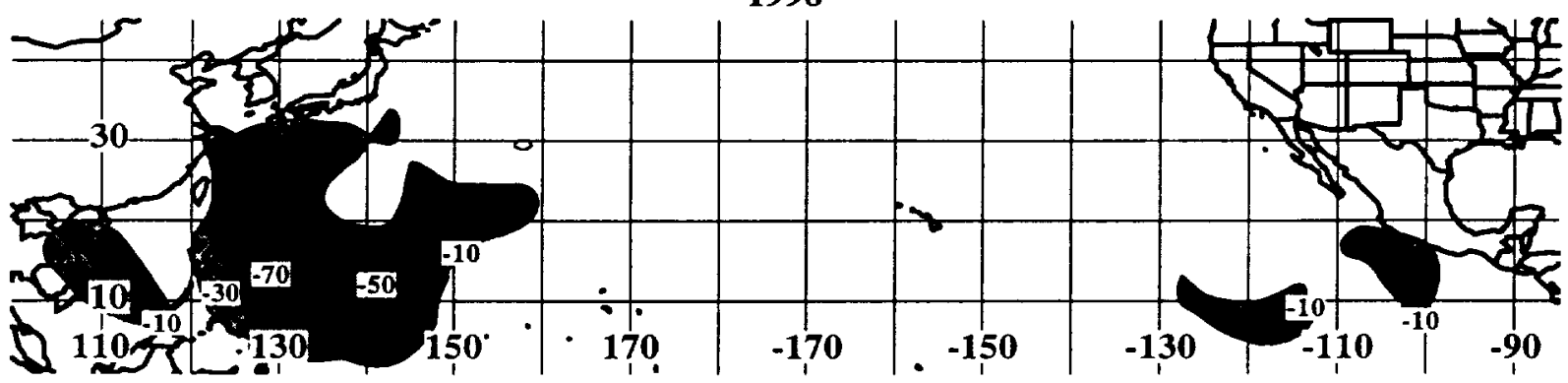




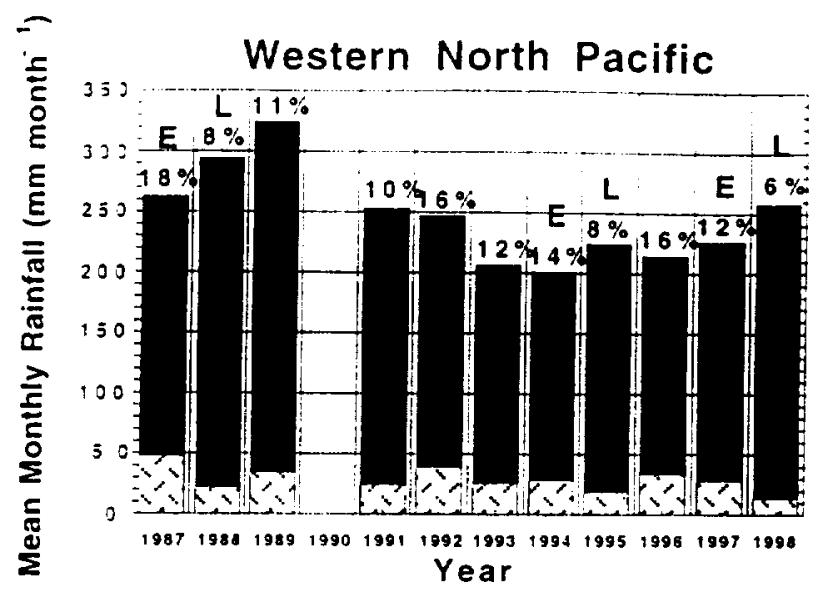

a

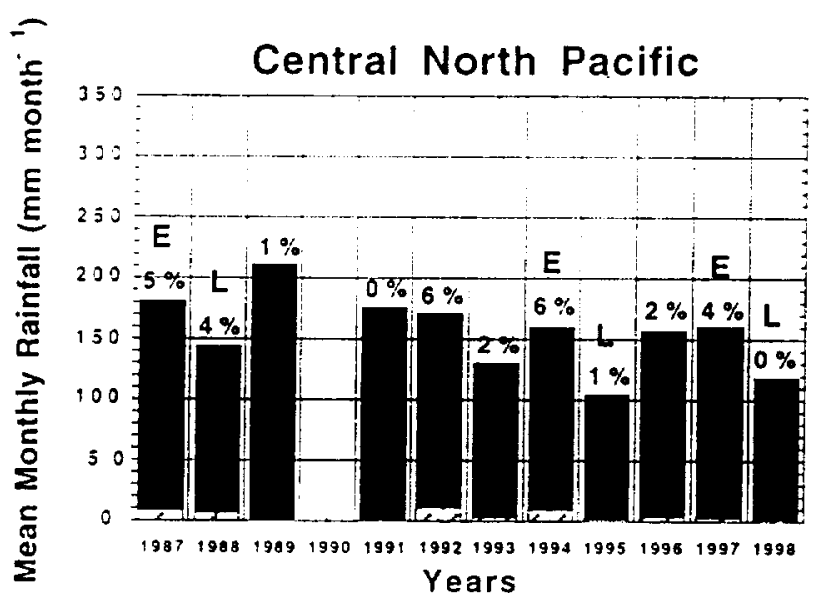

b

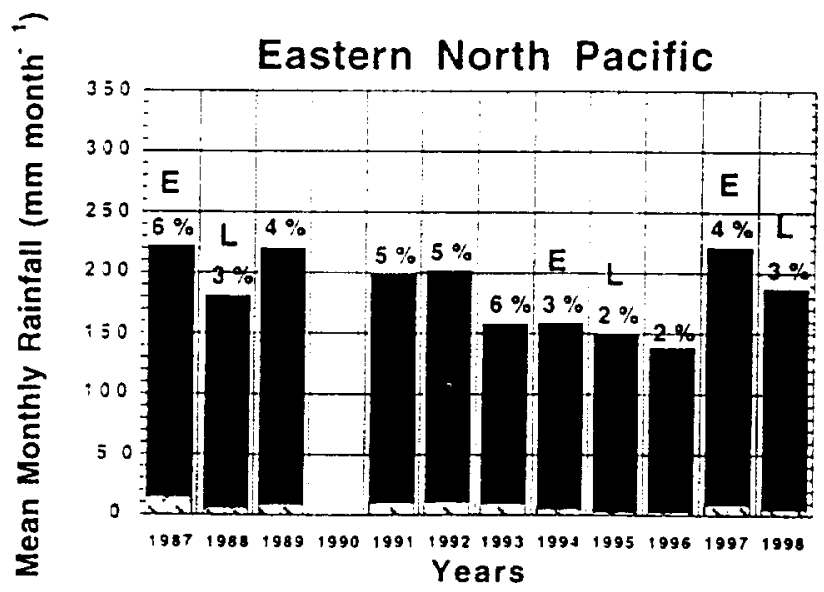

Fig. 10 


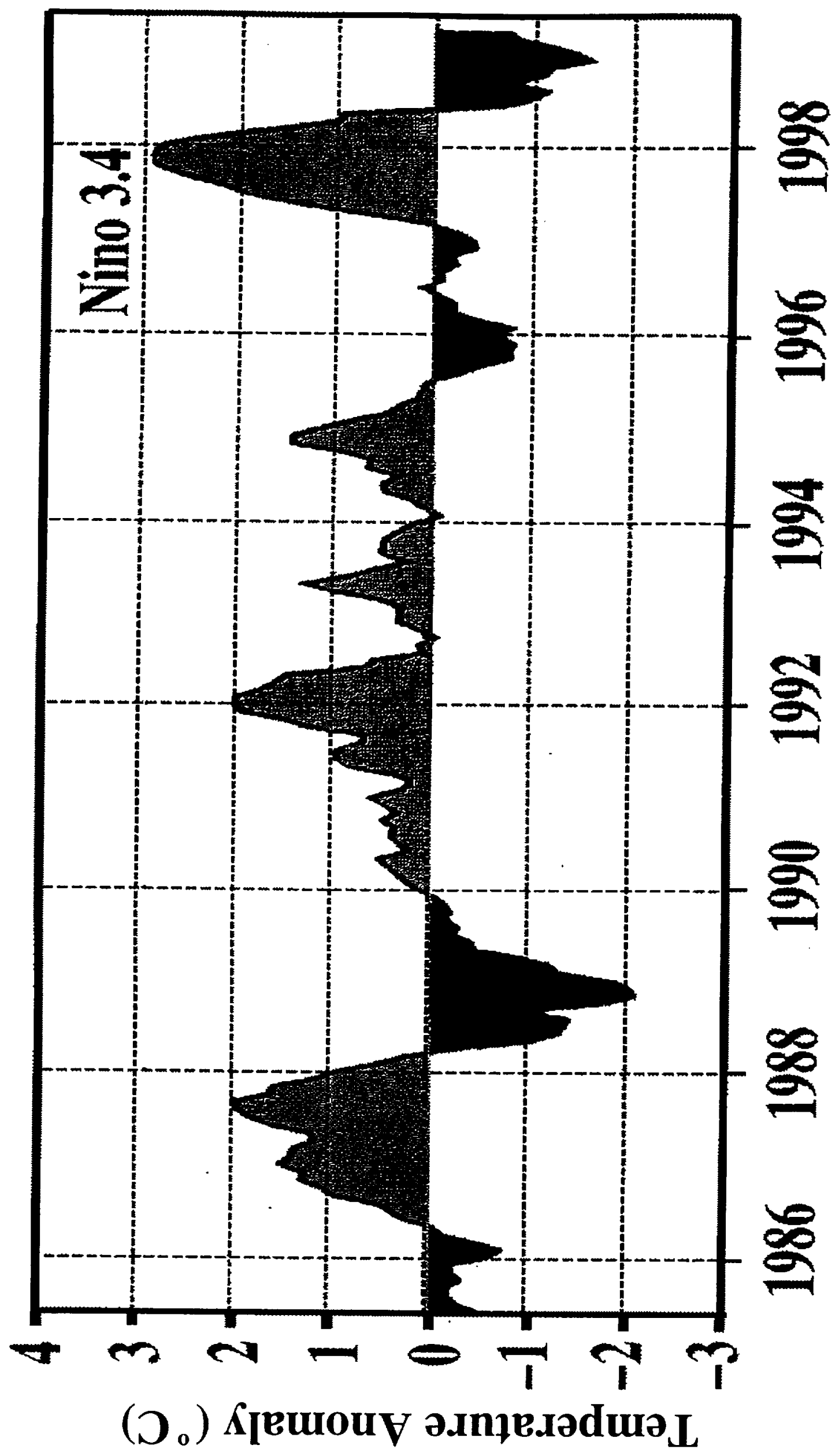



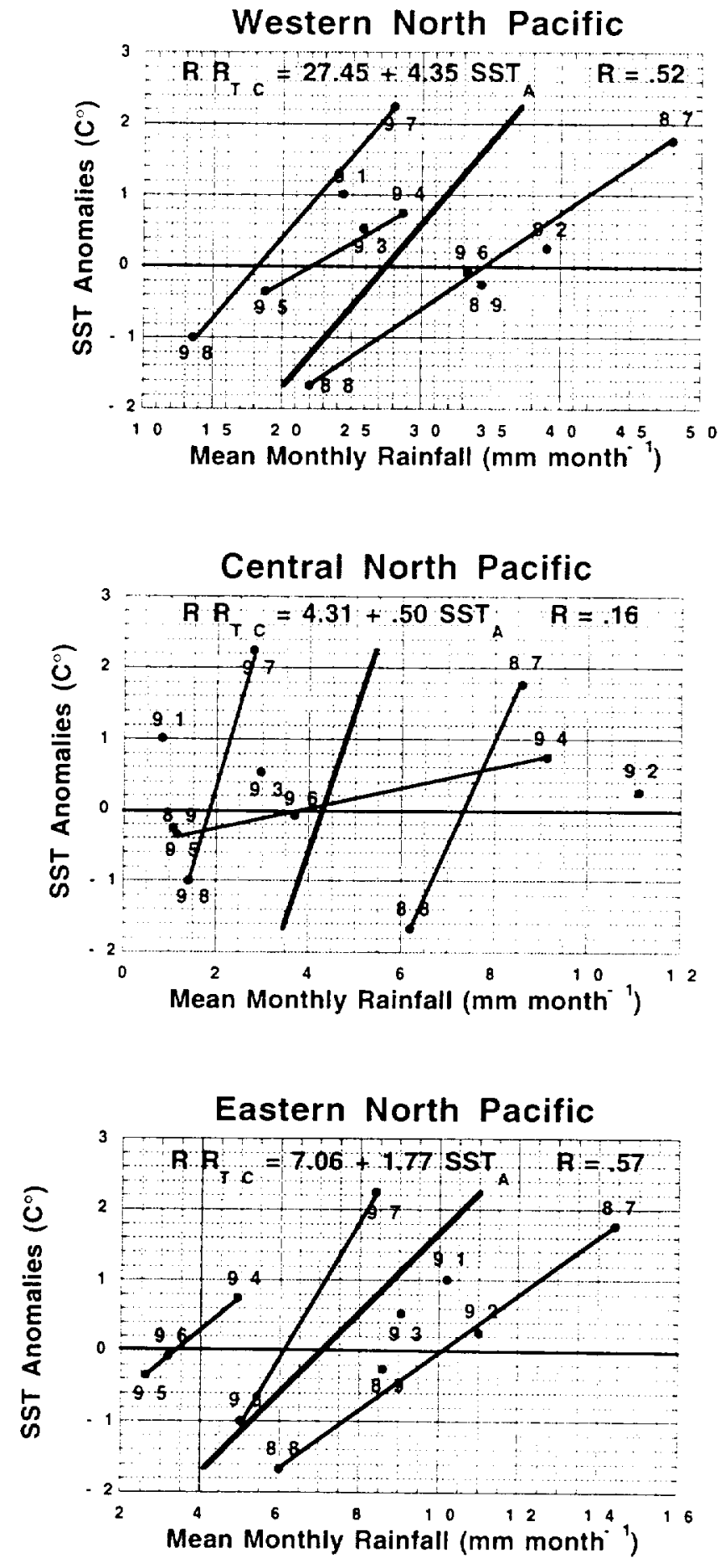

Fig. 12 

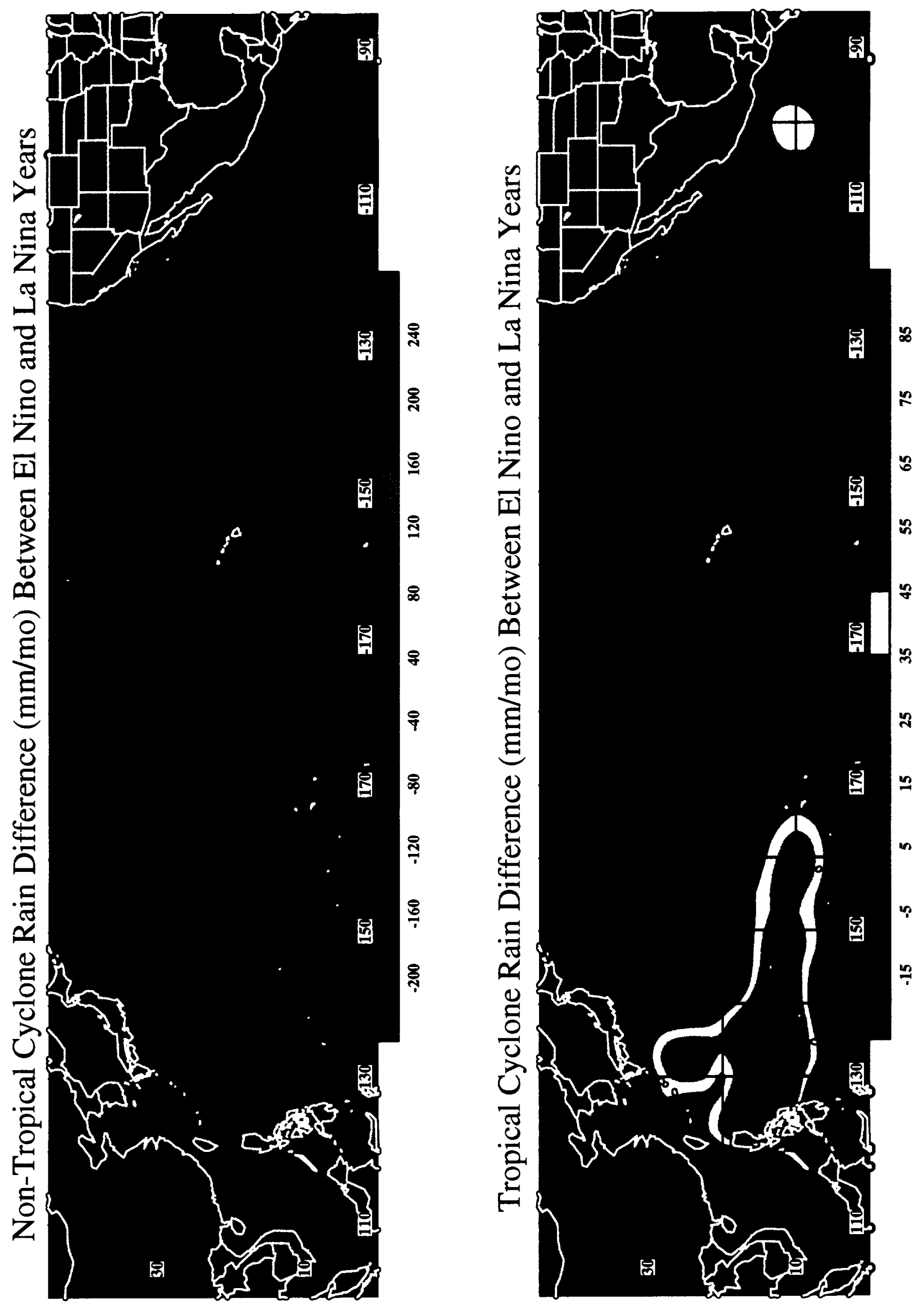

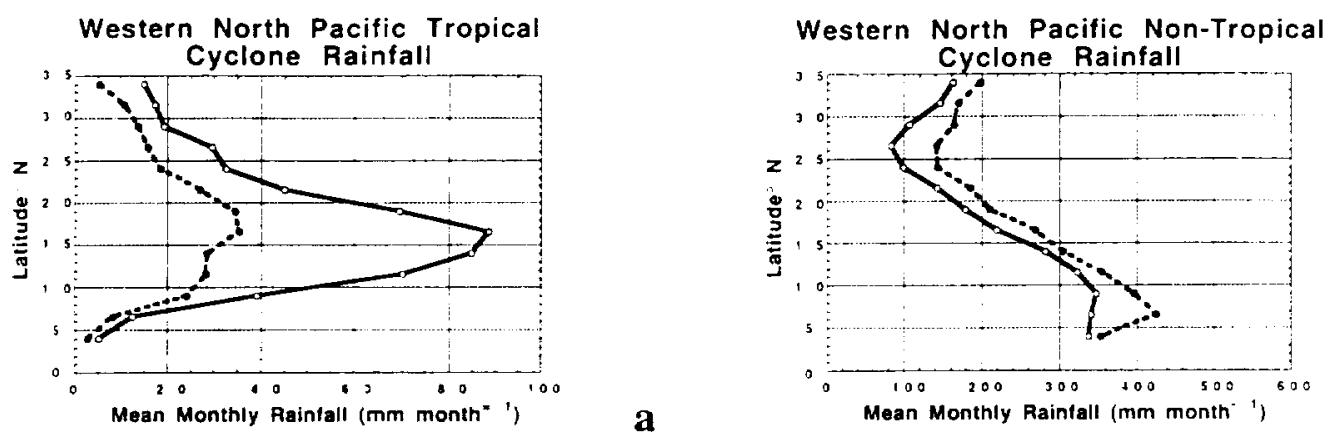

b
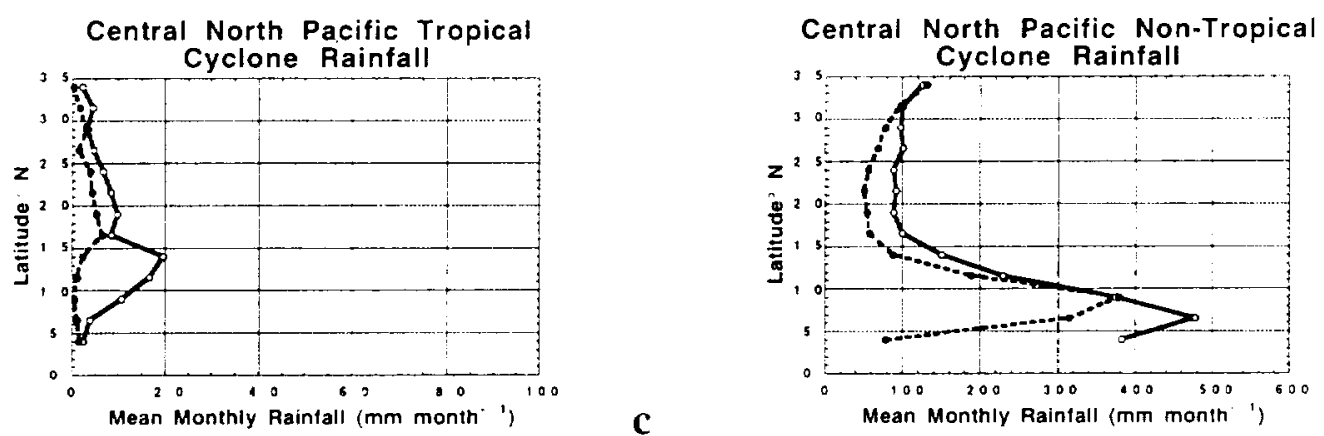

d
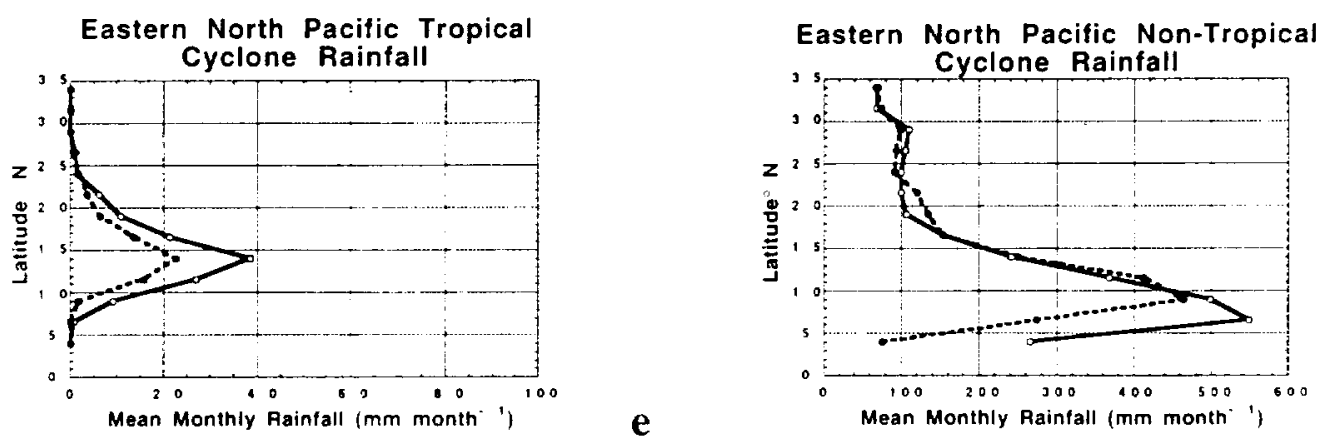

Fig. 14 


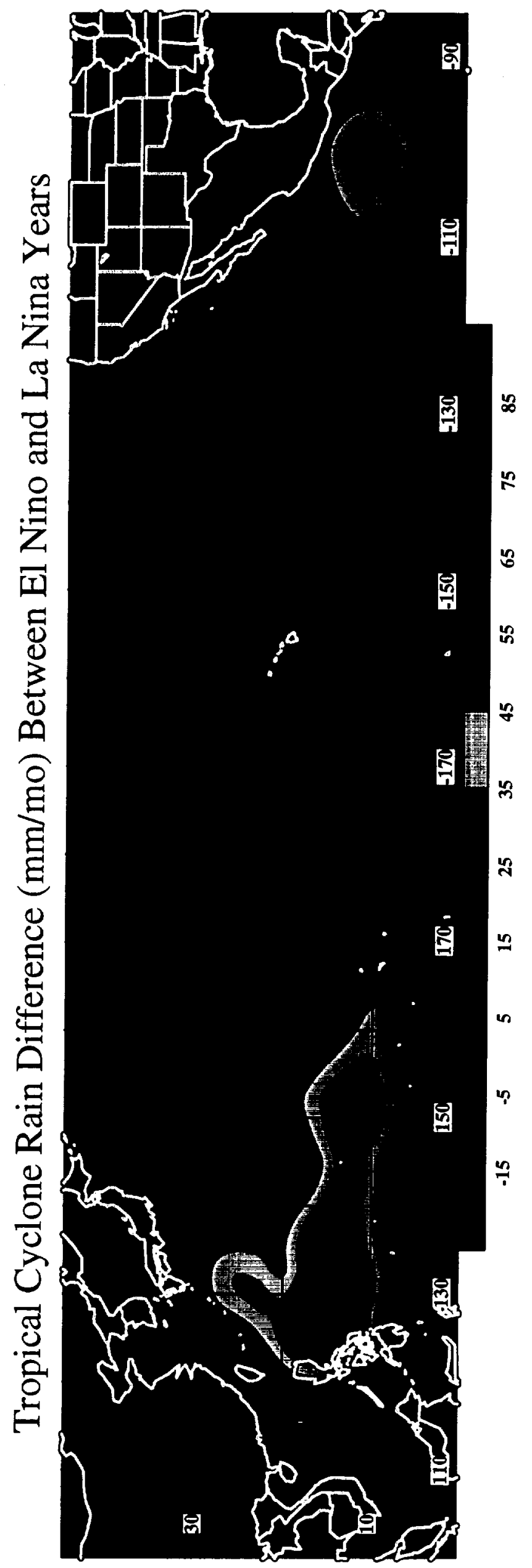



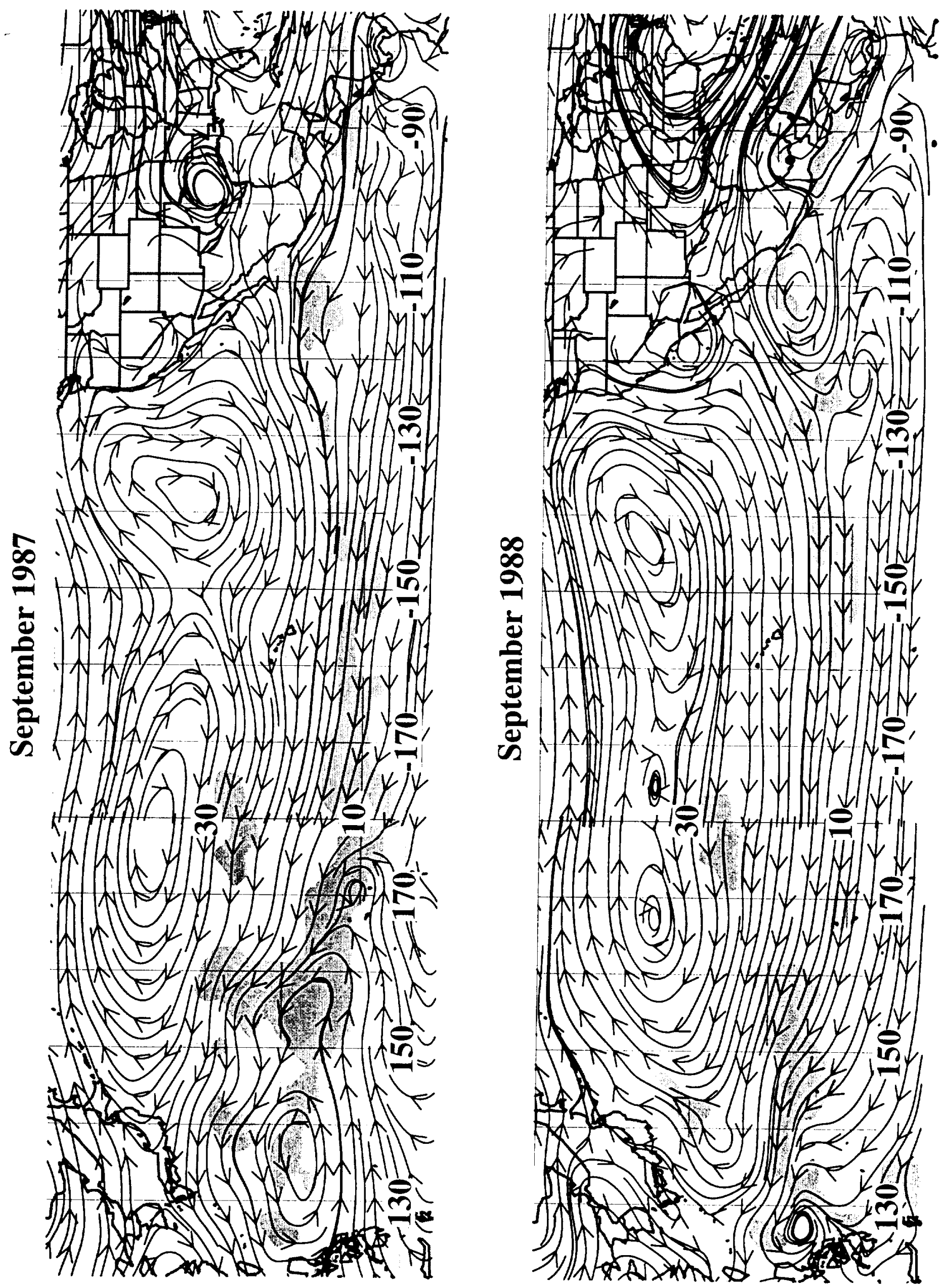


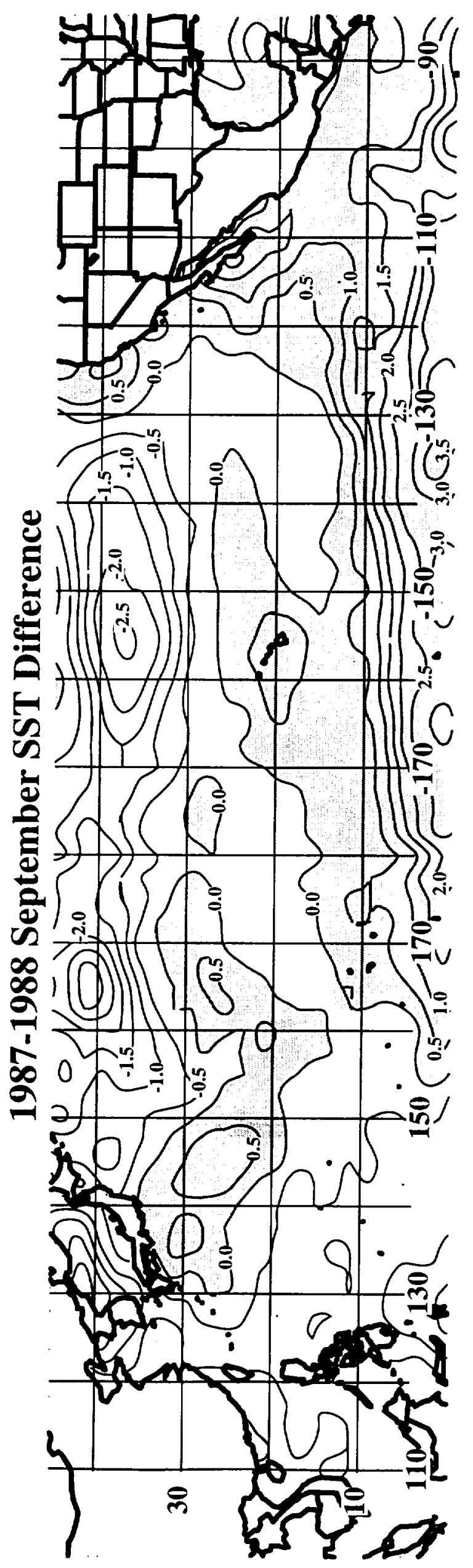

